\title{
Review Article \\ Potential Health Benefits of Deep Sea Water: A Review
}

\author{
Samihah Zura Mohd Nani, ${ }^{1,2,3}$ F. A. A. Majid, ${ }^{2,3,4}$ A. B. Jaafar, ${ }^{2,5}$ \\ A. Mahdzir, ${ }^{1,2}$ and M. N. Musa ${ }^{2}$ \\ ${ }^{1}$ Malaysian-Japan International Institute of Technology, Universiti Teknologi Malaysia, 54100 Kuala Lumpur, Malaysia \\ ${ }^{2}$ UTM Ocean Thermal Energy Centre (OTEC), Universiti Teknologi Malaysia, 54100 Kuala Lumpur, Malaysia \\ ${ }^{3}$ Tissue Culture Engineering Research Laboratory, Faculty of Chemical Engineering, Universiti Teknologi Malaysia, \\ 81310 Skudai, Johor, Malaysia \\ ${ }^{4}$ Institute of Marine Biotechnology, Universiti Malaysia Terengganu, 23000 Kuala Terengganu, Terengganu, Malaysia \\ ${ }^{5}$ Perdana School of Science, Technology, Innovation and Policy, Universiti Teknologi Malaysia, 54100 Kuala Lumpur, Malaysia
}

Correspondence should be addressed to Samihah Zura Mohd Nani; samihahzura@gmail.com

Received 8 June 2016; Accepted 27 October 2016

Academic Editor: Norman Temple

Copyright (C) 2016 Samihah Zura Mohd Nani et al. This is an open access article distributed under the Creative Commons Attribution License, which permits unrestricted use, distribution, and reproduction in any medium, provided the original work is properly cited.

\begin{abstract}
Deep sea water (DSW) commonly refers to a body of seawater that is pumped up from a depth of over $200 \mathrm{~m}$. It is usually associated with the following characteristics: low temperature, high purity, and being rich with nutrients, namely, beneficial elements, which include magnesium, calcium, potassium, chromium, selenium, zinc, and vanadium. Less photosynthesis of plant planktons, consumption of nutrients, and organic decomposition have caused lots of nutrients to remain there. Due to this, DSW has potential to become a good source for health. Research has proven that DSW can help overcome health problems especially related to lifestyle-associated diseases such as cardiovascular disease, diabetes, obesity, cancer, and skin problems. This paper reviews the potential health benefits of DSW by referring to the findings from previous researches.
\end{abstract}

\section{Introduction}

Water is generally defined as a liquid which is shaped by the container that it is filled in and is able to have many variants of colours. It is the crucial component for all living things. For instance, humans need water for many functions such as to regulate body temperature, enhance body metabolism, and provide minerals that are essential to the body. There are many sources of water, such as surface water, aquifer, spring, and seawater. Meanwhile, deep sea water (DSW) can also be a good water source. It is beneficial as it could supply minerals that are essential to health. DSW commonly refers to seawater that is pumped up from a depth of over $200 \mathrm{~m}$. It is usually associated with the following characteristics: low temperature, high purity, and being rich in nutrients, namely, beneficial elements [1]. Its location being far from solar radiation results in it having minimal to no bacteria activities. Less photosynthesis of plant plankton, consumption of nutrients, and lots of organic decomposition causes abundant nutrients to remain there. The abundance of inorganic material becomes higher when the depth of the seawater is increased. These characteristics have derived attention for research regarding DSW especially for its numerous beneficial minerals, which include magnesium $(\mathrm{Mg})$, calcium $(\mathrm{Ca})$, potassium $(\mathrm{K})$, chromium $(\mathrm{Cr})$, selenium (Se), zinc $(\mathrm{Zn})$, and vanadium $(\mathrm{V})[1,2]$. DSW is claimed to be high in minerals compared to other sources of water [2].

People usually consume drinking water that is in the form of bottled drinking water (such as mineral water), filtered tap water, or boiled tap water. Drinking water sold by suppliers is expected to contain good nutrient content and be safe to be consumed, because the suppliers possess a production license from the authorities. Surprisingly, some drinking water that is available in the market has been reported to have low mineral content [3]. This is possibly due to the common process drinking water undergo such as reverse osmosis and filtration, which removes the mineral contents inside it. Mineral water, which does not undergo the extensive process 
needed, is completely taken from groundwater and gains mineral ions from its sources such as rocks. It is also reported to contain low minerals [3]. However, the mineral contents in the water may vary with the geographical locations and the treatment process that it has gone through. Promisingly, DSW can offer plenty of minerals for the production of drinking water, and other DSW by-products. The production of refined DSW usually involves a desalination process, followed by a mineralization process. A high concentration of mineral salts in DSW though will commonly be processed through means such as reverse osmosis, electrodialysis, or low vacuum temperature in order to produce a safe concentration of water for consumption $[1,4,5]$.

DSW has been acquired from many countries with sources of it that are accessible to land. This include Korea, Japan, Taiwan, China, and the USA $[1,2,6,7]$. Most of those countries conducted researches regarding the health effects that can be attained from the consumption of DSW. As a result, the production of products such as deep sea drinking water (DSDW) became available from those countries. DSDW is claimed as a drinking water which can promote health, since it does not contain carbohydrate, fat, protein, and other bioactive materials which potentially cause adverse health effects, instead of providing valuable minerals to health. Despite being produced for drinking water, it is also used for a variety of purposes such as for food products, cosmetics, aquaculture, and agriculture [8]. Thus, due to the availability of numerous minerals, many researches have been conducted regarding it, in order to discover its benefits to health. By conducting literature reviews, the findings regarding the potential health benefits of DSW applications have been compiled and discussed in this paper.

\section{Minerals in Deep Sea Water}

DSW contains many types of minerals, such as $\mathrm{Mg}, \mathrm{Ca}, \mathrm{Cl}$, $\mathrm{Na}, \mathrm{K}, \mathrm{Se}$, and $\mathrm{V}$, as shown in Table 1 [8]. In fact, DSW is more abundant in minerals compared to surface seawater [6]. The example of the difference between the amount of minerals among surface seawater and DSW is shown in Table 2. DSW is a good nutrient source and could be claimed as a nutrients provider, since the minerals contained inside it provide many benefits to health. For instance, $\mathrm{Mg}$ is significant for many physiological processes in the body such as for energy metabolism and enzyme functions [9]. $\mathrm{Mg}$ is able to reduce lipids accumulation in the aorta of subjects that has high cholesterol intake [10]. Besides that, $\mathrm{Mg}$ is beneficial to people who have cardiovascular disease as it can reduce the potential of a heart attack by dilating the blood vessels and stopping spasms in the heart muscles and vessel walls [11]. It is also able to reduce the risk of obesity, diabetes, and asthma $[1,12]$. Drinking water, which has high Mg content, has shown higher inhibitory effects in the adipocyte differentiation, which means that the synthesis of fat cells is able to be slowed down by $\mathrm{Mg}$ [13]. Ca is one of the major minerals for humans. It has many benefits to health such as for bone development and density and acts as the pivotal cofactor for several enzymes needed for energy metabolism. Adequate intake of Ca can help reduce the risks of cardiovascular disease, obesity, and some forms of cancers $[1,9,12]$. A high Ca diet is able to increase lipolysis and preserve thermogenesis during caloric restriction, in a way that markedly accelerates weight loss [14]. $\mathrm{Cr}$ is an essential nutrient that is required for carbohydrates and lipids metabolism $[15,16]$. It has antioxidant properties which are useful for expanding cell life [17]. $\mathrm{V}$ has the potential for reducing lipids and has shown effectiveness in inhibiting adipocyte differentiation of the fat cells [18]. There are lots of benefits of other elements in DSW to health, which remain to be elucidated, particularly for the trace elements. The total amount of each element contained in DSW has been estimated [8], based upon the average concentration of each element in DSW. The total volume of DSW of $1.35 \times 10^{18} \mathrm{~m}^{3}$ is shown in Table 1.

\section{Potential Benefits of Deep Sea Water to Health}

Many researchers and scientists have done studies about DSW, particularly about refined or balanced DSW. The minerals in it have been proven to improve many health problems. The potential health benefits of DSW are described below by providing some of the mechanisms involved. The findings that have been reviewed in this paper are significant, and comparisons have been made between the treated group and the control group.

3.1. Improvement of the Cholesterol Profiles. The most promising benefits that can be attained from DSW intake are that it is able to improve the cholesterol profiles in the serum and liver, respectively. Its applications have reduced the levels of triglyceride (TG), non-high-density lipoprotein cholesterol (non-HDL-C) levels, and total cholesterol (TC) in the serum and liver of animal models, respectively [4-6, 19-22, 24]. Drinking water produced from DSW which contains $\mathrm{Mg}$ of 600 and $1000 \mathrm{ppm}$, is able to decrease cholesterol levels by $18 \%$ and $15 \%$, respectively [22]. Interestingly, a study of DSW consumption by hypercholesterolemic individuals proved that it could reduce TC and low density lipoproteins (LDL) and decreased lipid peroxidation in those subjects. The mechanisms for the improvement of cholesterol profiles are associated with the upregulation of hepatic low density lipoprotein receptor and cholesterol-7a-hydroxylase (CYP7A1) gene expressions, which are involved in cholesterol catabolism. A DSW intake resulted in a higher faecal cholesterol and bile acid excretions, thus decreasing the TC levels [5]. DSW decreases the lipid contents of hepatocytes through the activation of AMP-activated protein kinase, inhibiting the synthesis of cholesterol and fatty acid [19]. The details of respective studies are described in Table 3.

3.2. Protection from Cardiovascular Problems. DSW provides protection from cardiovascular diseases by decreasing the TC, TG, atherogenic index, and malondialdehyde (MDA) levels, while increasing the serum trolox equivalent antioxidant capacity (TEAC). The molecular mechanism of its cardiovascular protection is via upregulation of hepatic low density lipoprotein receptors (LDL receptors) and CYP7A1 gene expressions [5]. The cardioprotective effects of it were 
TABLE 1: Total amount of elements in deep sea water [8].

\begin{tabular}{|c|c|}
\hline Element & Total ( $10^{6}$ ton $)$ \\
\hline CI & $26,120,000,000$ \\
\hline $\mathrm{Na}$ & $14,550,000,000$ \\
\hline $\mathrm{Mg}$ & $1,728,000,000$ \\
\hline S & $1,312,000,000$ \\
\hline $\mathrm{Ca}$ & $556,000,000$ \\
\hline $\mathrm{K}$ & $538,000,000$ \\
\hline $\mathrm{Br}$ & $90,000,000$ \\
\hline $\mathrm{C}$ & $36,000,000$ \\
\hline $\mathrm{N}$ & $11,700,000$ \\
\hline $\mathrm{Sr}$ & $10,500,000$ \\
\hline B & $6,100,000$ \\
\hline $\mathrm{O}$ & $3,800,000$ \\
\hline $\mathrm{Si}$ & $3,800,000$ \\
\hline $\mathrm{F}$ & $1,900,000$ \\
\hline $\mathrm{Ar}$ & 840,000 \\
\hline $\mathrm{Li}$ & 240,000 \\
\hline $\mathrm{Rb}$ & 160,000 \\
\hline$P$ & 84,000 \\
\hline I & 78,000 \\
\hline $\mathrm{Ba}$ & 20,000 \\
\hline Mo & 14,000 \\
\hline $\mathrm{U}$ & 4,300 \\
\hline $\mathrm{V}$ & 2,700 \\
\hline As & 1,600 \\
\hline $\mathrm{Ni}$ & 650 \\
\hline $\mathrm{Zn}$ & 470 \\
\hline $\mathrm{Kr}$ & 420 \\
\hline Cs & 413 \\
\hline $\mathrm{Cr}$ & 271 \\
\hline $\mathrm{Sb}$ & 270 \\
\hline $\mathrm{Ne}$ & 216 \\
\hline $\mathrm{Se}$ & 209 \\
\hline $\mathrm{Cu}$ & 202 \\
\hline $\mathrm{Cd}$ & 94 \\
\hline $\mathrm{Xe}$ & 89 \\
\hline $\mathrm{Fe}$ & 40 \\
\hline $\mathrm{Al}$ & 40 \\
\hline $\mathrm{Mg}$ & 27 \\
\hline $\mathrm{Y}$ & 22 \\
\hline $\mathrm{Zr}$ & 20 \\
\hline TI & 17 \\
\hline W & 13 \\
\hline $\operatorname{Re}$ & 11 \\
\hline $\mathrm{He}$ & 10 \\
\hline $\mathrm{Ti}$ & 8.8 \\
\hline $\mathrm{La}$ & 7.6 \\
\hline
\end{tabular}

TABLE 1: Continued.

\begin{tabular}{|c|c|}
\hline Element & Total (10 ton $)$ \\
\hline $\mathrm{Ge}$ & 2.4 \\
\hline $\mathrm{Nb}$ & $<7$ \\
\hline $\mathrm{Hf}$ & 4.6 \\
\hline $\mathrm{Nd}$ & 4.4 \\
\hline $\mathrm{Ta}$ & $<3$ \\
\hline $\mathrm{Ag}$ & 2.7 \\
\hline Co & 1.6 \\
\hline $\mathrm{Ga}$ & 1.6 \\
\hline Er & 1.6 \\
\hline $\mathrm{Yb}$ & 1.6 \\
\hline Dy & 1.5 \\
\hline Gd & 1.2 \\
\hline $\operatorname{Pr}$ & 0.9 \\
\hline $\mathrm{Ce}$ & 0.9 \\
\hline $\mathrm{Se}$ & 0.9 \\
\hline $\mathrm{Sm}$ & 0.8 \\
\hline Sn & 0.7 \\
\hline Ho & 0.5 \\
\hline $\mathrm{Lu}$ & 0.3 \\
\hline $\mathrm{Be}$ & 0.3 \\
\hline $\mathrm{Tm}$ & 0.3 \\
\hline $\mathrm{Eu}$ & 0.2 \\
\hline $\mathrm{Hg}$ & 0.2 \\
\hline $\mathrm{Rh}$ & 0.1 \\
\hline $\mathrm{Te}$ & 0.1 \\
\hline $\mathrm{Pd}$ & 0.008 \\
\hline $\mathrm{Pt}$ & 0.07 \\
\hline $\mathrm{Bi}$ & 0.04 \\
\hline $\mathrm{Au}$ & 0.03 \\
\hline Th & 0.02 \\
\hline In & 0.01 \\
\hline $\mathrm{Ru}$ & $<0.006$ \\
\hline Os & 0.003 \\
\hline $\mathrm{Ir}$ & 0.0002 \\
\hline
\end{tabular}

further proven, when its application can reduce abnormal cardiac architecture and apoptosis and enhance insulin-like growth factor-1 receptor (IGF-1R) cardiac survival signalling [25]. DSW can also improve cardiovascular hemodynamics in the study conducted by Katsuda et al. [2]. More details about the protective effects of DSW on the cardiovascular system are described in Table 4.

3.3. Prevention from Atherogenesis. Atherogenesis is the formation of plaque in the inner lining of an artery, which deposits fatty substances, cholesterol, cellular waste products, calcium, and other substances. Treatment with DSW was able to prevent the atherogenesis process $[6,21]$. DSW with the hardness of 300,900 , and 1500 had significantly decreased the atherogenic index [(TC - HDL-C)/HDL-C] 
TABLE 2: Amount of elements in the surface seawater and deep sea water [6].

\begin{tabular}{lcc}
\hline Type of element & Surface seawater $(\mathrm{mg} / \mathrm{L})$ & Deep sea water $(\mathrm{mg} / \mathrm{L})$ \\
\hline $\mathrm{Na}$ & 10800 & 7240 \\
$\mathrm{~K}$ & 392 & 10400 \\
$\mathrm{Ca}$ & 411 & 39 \\
$\mathrm{Mg}$ & 1290 & 96100 \\
$\mathrm{Sr}$ & 8.1 & 0.17 \\
$\mathrm{~B}$ & 4.45 & 320 \\
$\mathrm{Fe}$ & 0.003 & 0.25 \\
$\mathrm{Li}$ & 0.17 & 11.7 \\
$\mathrm{Cu}$ & 0.0009 & 0.22 \\
$\mathrm{Co}$ & 0.0004 & 0.26 \\
$\mathrm{Mo}$ & 0.01 & 0.62 \\
$\mathrm{Ni}$ & 0.0066 & 0.11 \\
$\mathrm{Cr}$ & 0.0002 & 0.087 \\
$\mathrm{Rb}$ & 0.12 & 1.2 \\
$\mathrm{Si}$ & 2.9 & 0.5 \\
$\mathrm{~V}$ & 0.002 & 1.2 \\
$\mathrm{~F}$ & 13 & 21.8 \\
$\mathrm{Br}$ & 67.3 & 5400 \\
$\mathrm{I}$ & 0.064 & 5.5 \\
\hline
\end{tabular}

[5]. Antiatherogenic effects of DSW are associated with 5adenosine monophosphate-activated protein kinase (AMPK) stimulation and the consequent inhibition of phosphorylation of acetyl-CoA carboxylase (ACC) [6]. AMPK plays an important role in lipid metabolism via the inhibition of 3Hydroxy-3-methyl-glutaryl-CoA reductase (HMGCR) and ACC and then inhibits the production of cholesterol. The details of these studies are described in Table 5. Prevention of atherogenesis may avoid severe health problems, including coronary heart disease and stroke. DSW has antiatherogenic properties due to the existence of many beneficial mineral ions such as $\mathrm{Mg}$ and $\mathrm{Ca}$ in it. Hence, it could be widely promoted to enhance cardiovascular protection.

3.4. Reduction of Blood Pressure. DSW could improve cardiovascular hemodynamics and reduce blood pressure [2, $6,20]$. Hypertensive rats that were treated with DSW for eight weeks had lower blood pressure than the control group [20]. Reduced fats and blood lipids, such as in the artery, may be associated with the reduced blood pressure. Although DSW used in the study contains pretty much salt, the blood pressure did not increase. In another study [5], DSW application did not affect the blood pressure. Moreover, DSW can also prevent thrombotic disorder by suppressing the release of type-1 plasminogen activator inhibitor from the human vascular endothelial cells [7]. Lots of minerals combination in the DSW, such as $\mathrm{Mg}, \mathrm{Ca}$, and $\mathrm{Na}$ are associated with a reduced blood pressure. Na content may induce hypertension, though Mg supplement might lower the blood pressure by suppressing the adrenergic activity and, likely, natriuresis [46]. It is interesting that high $\mathrm{Mg}$ content can lower blood pressure in the presence of sodium. The details of these respective studies are described in Table 6.

3.5. Protection from Obesity. DSW has antiobesity properties and has been proven to reduce fat and body weight [1, $27,29,45]$. It has been recognized as possible antiobesity therapeutics from nature [47]. The research has reported that DSW was significantly able to reduce lipids accumulation in the in vitro and in vivo models. Study with obese mice elucidated that DSW with hardness of 1000 was able to reduce body weight by $7 \%$. It also increased the plasma protein levels of adiponectin and decreased plasma protein levels of resistin, RBP4, and fatty acid binding protein $[1,29]$. The results suggest that the antiobesity activities were mediated by modulating the expression of obesity-specific molecules. The expression of key adipogenic genes such as peroxisome proliferatoractivated receptor- $\gamma$ (PPAR $\gamma)$, CCAAT/enhancer-binding protein- $\alpha(\mathrm{C} / \mathrm{EBP} \alpha)$, and adipocyte protein-2 (aP2) was suppressed, and the expression of glucose transporter 4 (GLUT4) was increased by its application $[1,27]$. The magnificent effects of DSW on obesity were further proven when it stimulated mitochondrial biogenesis, the component which controls the release of energy associated with lipid metabolism [26]. $\mathrm{Mg}$ and $\mathrm{Ca}$ ions play a role as the main active components to reduce fats. However, DSW that has the same hardness of 1000 with drinking water which only contains $\mathrm{Mg}$ and $\mathrm{Ca}$ ions has showed small different effects in the obesity finding [13]. Thus, this hypothesized that $\mathrm{Mg}$ and $\mathrm{Ca}$ are not the main factors to reduce fats, as the roles of many elements in DSW remain to be elucidated. However the available findings on the clinical study showed that there is no significant difference of TG level and body weight, between treated subjects and controls [4]. More clinical studies are warranted. The detailed mechanisms involved regarding the effects of DSW on obesity-specific molecules are described in Table 7.

3.6. Treatment for Diabetes. DSW was able to improve glucose intolerance and suppress hyperglycaemia which indicated its ability to treat diabetes [26, 27, 29]. Its application had recovered the size of the pancreatic islets of Langerhans and increased the secretion of glucagon and insulin. Through quantitative reverse transcription polymerase chain reaction, DSW showed improvement results regarding the expression of hepatic genes involved in glycogenolysis and glucose oxidation. Whereas in muscles, glucose uptake, $\beta$-oxidation, and glucose oxidation were increased by its supplementation [29]. DSW increased the phosphorylation of IRS-1, LKB1, AMPK, and mTOR, which are signalling molecules related to lipid and glucose metabolism [27]. Moreover, blood glucose in treated mice was reduced by its application [27, 29]. The plasma glucose levels in DSW-fed mice were substantially reduced by $35.4 \%$, compared to the control mice group [1]. The antidiabetic properties of it were associated with the existence of mineral ions such as $\mathrm{Mg}$ and $\mathrm{Ca}$. The details of these studies are described in Table 8.

3.7. Treatment for Skin Problems. DSW is also capable of treating skin problems. In a study involving patients with 
TABLE 3: Effects of deep sea water on cholesterol levels.

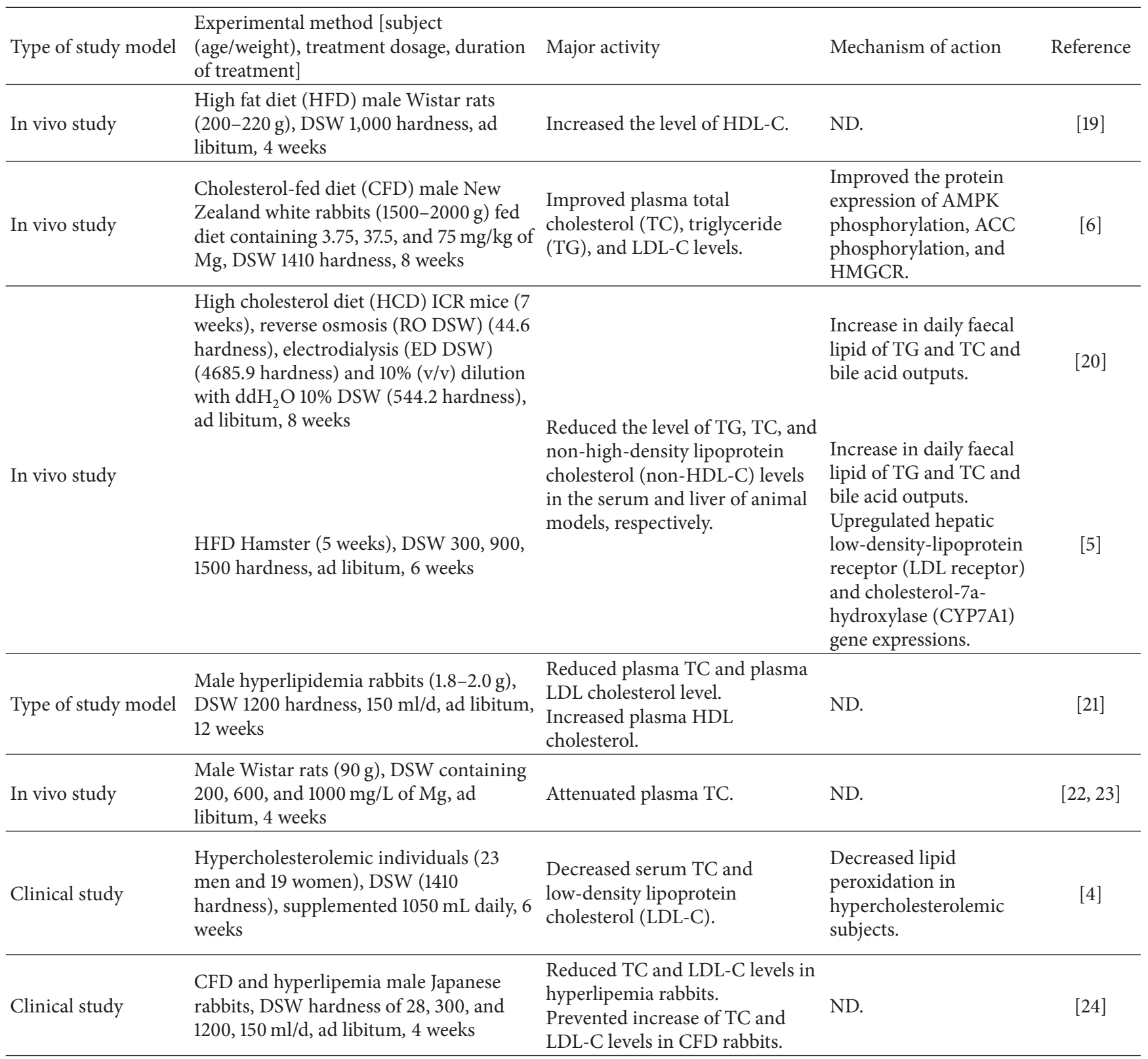

ND: not described.

atopic eczema/dermatitis syndrome (AEDS) treated with DSW, the improvement of skin symptoms such as inflammation, lichenification, and cracking of the skin was observed [31]. AEDS patients typically exhibit an imbalance of various essential minerals in hair, and some have toxic minerals present. From that study, DSW intake has restored the essential minerals such as Se and reduces the levels of toxic minerals such as mercury and lead in the treated patients. In another study, the intake of DSW has reduced allergic skin responses and serum levels of total IgE, Japanese cedar pollen-specific IgE, interleukin-4 (IL-4), IL-6, IL-13, and IL18 in the patients with allergic rhinitis, compared to the distilled water intake which fails to give those effects [32].
In vivo study revealed that DSW can recover the atopic skin lesion by improving the skin symptoms such as edema, erythema, dryness, itching, transepidermal water loss (TEWL), decreased epidermal thickness, and infiltration of inflammatory cells. Its application can reduce allergic responses when reduction of total IgE levels and histamine released were recorded. It also inhibited upregulation of $\mathrm{IgE}$, histamine, and proinflammatory cytokines (tumor necrosis factor $\alpha$ (TNF- $\alpha$ ), IL- $1 \beta$, and IL-6) in the serum. Downregulated CD4+/CD8+ ratio in spleen lymphocyte by $10 \%$ CDSW was also observed. Its application can reduce the expression of IL4 and IL-10 from Th2 cells in the 10\% CDSW-treated group [30]. The details of these studies are described in Table 9. 
TABLE 4: Effects of deep sea water on cardiovascular protection.

\begin{tabular}{|c|c|c|c|c|}
\hline $\begin{array}{l}\text { Type of study } \\
\text { model }\end{array}$ & $\begin{array}{l}\text { Experimental method [subject } \\
\text { (age/weight), treatment dosage, } \\
\text { duration of treatment] }\end{array}$ & Major activity & Mechanism of action & Reference \\
\hline In vivo study & $\begin{array}{l}\text { HCD ICR mice ( } 7 \text { weeks), } \\
\text { reverse osmosis-DSW } 44.6 \\
\text { hardness, Electrodialysis-DSW } \\
4685.9 \text { hardness, } 10 \% \text { DSW } 544.2 \\
\text { hardness, } 8 \text { weeks }\end{array}$ & $\begin{array}{l}\text { Reduced abnormal cardiac } \\
\text { architecture, apoptosis in left } \\
\text { ventricle (LV). } \\
\text { Increased cardiac survival } \\
\text { signalling components in LV of } \\
\text { mice. } \\
\text { Change in Fas and } \\
\text { mitochondrial-dependent } \\
\text { apoptotic components in LV of } \\
\text { mice. } \\
\text { Change in apoptosis related } \\
\text { proteins and cardiac apoptotic } \\
\text { cells in LV of mice. }\end{array}$ & $\begin{array}{l}\text { Decreased LV diameter, LV thickness, } \\
\text { and ratio of thickness to diameter in } \\
\text { hearts. } \\
\text { Increased insulin-like growth factor-1 } \\
\text { receptor, phosphoinositide-3-kinases, } \\
\text { and p-AKT/AKT ratio. } \\
\text { Decreased the protein products of } \\
\text { TNF- } \alpha \text { in LV of mice. } \\
\text { Decreased levels of Fas, cytochrome c, } \\
\text { cleaved caspase- } 9 \text {, t-Bid, and cleaved } \\
\text { caspase-3. } \\
\text { Decreased Bak and increased } \\
\text { antiapoptotic proteins, including } \\
\text { Bcl-XL and ratio of p-Bad to Bad. } \\
\text { Decreased TUNEL-positive cardiac } \\
\text { cells. }\end{array}$ & [25] \\
\hline In vivo study & $\begin{array}{l}\text { High fat/cholesterol-fed (HFCD) } \\
\text { male Syrian Golden hamster ( } 5 \\
\text { weeks), DSW 300, 900, and } 1500 \\
\text { hardness, ad libitum, } 6 \text { weeks }\end{array}$ & $\begin{array}{l}\text { Decreased levels of serum TC, } \\
\text { TG, atherogenic index, and } \\
\text { malondialdehyde. }\end{array}$ & $\begin{array}{l}\text { Increase in daily faecal lipid of TG and } \\
\text { TC and bile acid outputs. } \\
\text { Upregulated hepatic } \\
\text { low-density-lipoprotein receptor (LDL } \\
\text { receptor) and } \\
\text { cholesterol-7a-hydroxylase (CYP7A1) } \\
\text { gene expressions. } \\
\text { Increase of serum trolox equivalent } \\
\text { antioxidant capacity (TEAC). }\end{array}$ & {$[5]$} \\
\hline In vivo study & $\begin{array}{l}\text { Kurosawa and } \\
\text { Kusanagi-Hypercholesterolemic } \\
\text { (KHC) rabbits ( } 4 \text { months), DSW } \\
1000 \text { hardness, } 500 \mathrm{ml} / \mathrm{d}, 6 \\
\text { months }\end{array}$ & $\begin{array}{l}\text { Improved cardiovascular } \\
\text { hemodynamics. }\end{array}$ & $\begin{array}{l}\text { Lowered systolic, diastolic pulse, mean } \\
\text { arterial pressures, and total peripheral } \\
\text { resistance. }\end{array}$ & [2] \\
\hline
\end{tabular}

TABLE 5: Effects of deep sea water on atherosclerosis.

\begin{tabular}{|c|c|c|c|c|}
\hline $\begin{array}{l}\text { Type of study } \\
\text { model }\end{array}$ & $\begin{array}{l}\text { Experimental method [subject } \\
\text { (age/weight), treatment } \\
\text { dosage, duration of treatment] }\end{array}$ & Major activity & Mechanism of action & Reference \\
\hline In vivo study & $\begin{array}{l}\text { CFD male New Zealand white } \\
\text { rabbits }(1500-2000 \mathrm{~g}) \text { fed diet } \\
\text { contain } 3.75,37.5 \text {, and } \\
75 \mathrm{mg} / \mathrm{kg} \text { of } \mathrm{Mg} \text {, DSW } 1410 \\
\text { hardness, } 8 \text { weeks }\end{array}$ & $\begin{array}{l}\text { Reduced serum lipids, prevented } \\
\text { atherogenesis, and suppressed } \\
\text { serum cholesterol levels. } \\
\text { Reduced lipids accumulation in } \\
\text { liver tissues, and limited aortic } \\
\text { fatty streaks. }\end{array}$ & $\begin{array}{l}\text { Improved protein expression of } \\
\text { AMPK phosphorylation, ACC } \\
\text { phosphorylation, and HMGCR. }\end{array}$ & {$[6]$} \\
\hline In vivo study & $\begin{array}{l}\text { Male hyperlipidemia rabbits } \\
(1.8-2.0 \mathrm{~g}), \mathrm{DSW} 1200 \\
\text { hardness, } 150 \mathrm{ml} / \mathrm{d} \text {, ad libitum, } \\
12 \text { weeks }\end{array}$ & $\begin{array}{l}\text { Suppressed lipid deposition on } \\
\text { the inner wall of the aorta. } \\
\text { Suppressed foam cell formation. }\end{array}$ & $\begin{array}{l}\text { Reduced plasma TC, plasma LDL } \\
\text { cholesterol, and LPO. } \\
\text { Increased plasma HDL cholesterol. } \\
\text { Increased glutathione peroxidase } \\
\text { (GPx) activity. } \\
\text { Decreased plasma lipid peroxide } \\
\text { (TBARS) value. }\end{array}$ & {$[21]$} \\
\hline In vivo study & $\begin{array}{l}\text { CFD and hyperlipemia male } \\
\text { Japanese rabbits, DSW } \\
\text { hardness of } 28,300 \text {, and } 1200 \text {, } \\
150 \mathrm{ml} / \mathrm{d}, 4 \text { weeks }\end{array}$ & $\begin{array}{l}\text { Reduced TC and LDL-C levels in } \\
\text { hyperlipemia rabbits. } \\
\text { Prevented increase of TC and } \\
\text { LDL-C levels in CFD rabbits. } \\
\text { Reduced lipid accumulation in } \\
\text { liver and permeation of } \\
\text { macrophages in CFD rabbits. }\end{array}$ & ND. & [24] \\
\hline
\end{tabular}

ND: not described. 
TABLE 6: Effects of deep sea water on blood pressure.

\begin{tabular}{llll}
\hline $\begin{array}{l}\text { Type of study } \\
\text { model }\end{array}$ & $\begin{array}{l}\text { Experimental method [subject (age/weight), } \\
\text { treatment dosage, duration of treatment] }\end{array}$ & Major activity & Mechanism of action \\
\hline In vivo study & $\begin{array}{l}\text { Spontaneous hypertensive rats }(250-300 \mathrm{~g}) \mathrm{fed} \\
\text { diet containing 3.75, 37.5, and } 75 \mathrm{mg} / \mathrm{kg} \text { of } \mathrm{Mg}, \\
\text { DSW 1410 hardness, ad libitum, 8 weeks }\end{array}$ & $\begin{array}{l}\text { Decreased } \\
\text { blood pressure. }\end{array}$ & $\begin{array}{l}\text { Decreased systolic and } \\
\text { diastolic pressure. }\end{array}$ \\
\hline In vivo study & $\begin{array}{l}\text { Kurosawa and Kusanagi-Hypercholesterolemic } \\
\text { (KHC) rabbits (4 months), DSW 1000 } \\
\text { hardness, 500 ml/d, 6 months }\end{array}$ & $\begin{array}{l}\text { Decreased } \\
\text { blood pressure. }\end{array}$ & $\begin{array}{l}\text { Lowered systolic, diastolic } \\
\text { pulse, and mean arterial } \\
\text { pressure and total peripheral } \\
\text { resistance. }\end{array}$ \\
\hline
\end{tabular}

3.8. Protection from Hepatic Problems. High fat diets may cause problems to hepatic systems. DSW is able to give protection for hepatic problems. In a study by Chen et al. [33], it has decreased the lipid accumulation in livers, which are associated with the increase in daily faecal lipid and bile acid outputs. The hepatic antioxidative levels were also improved by its application, which were proven by the high capacity levels of liver glutathione and trolox equivalent antioxidant. DSW was able to regulate hepatic fatty acid homeostasis by upregulating genes related to b-oxidation of fatty acids, which are hepatic peroxisome proliferator-activated receptor-alpha, retinoid $\mathrm{X}$ receptor-alpha, and uncoupling protein- 2 gene expression. Its application can attenuate hepatic damage, which is proven by reduced lipid peroxidation status in livers, which might be related to reducing hepatic malondialdehyde (MDA) content [33]. The liver damage indices which are aspartate aminotransferase (AST) and alanine aminotransferase (ALT) are also reduced by its application. The details of these studies are described in Table 10.

3.9. Treatment for Fatigue. DSW can restore fatigue and improve exercise workload. Its application has promoted the endurance and reduced exhaustive period of rats in an exercise test [34]. The ratios of lactic acid elimination to lactic acid increment were improved in DSW treated rats. The study showed low blood urea nitrogen (BUN) level of rats fed with D100 in a dosage of $30 \mathrm{~mL} / \mathrm{kg} \cdot \mathrm{d}$ and D600 in dosages of 6,12 , and $30 \mathrm{~mL} / \mathrm{kg} \cdot \mathrm{d}$, respectively. As a result, the liver glycogen content had increased in the rats fed with D100 in a dosage of $6 \mathrm{~mL} / \mathrm{kg} \cdot \mathrm{d}$. Study regarding effects of DSW on human shows significant findings as well. DSW is able to accelerate recovery from physical fatigue of people, following an exhaustive physical challenge [35]. The findings suggested that DSW which has enriched contents of boron, magnesium, lithium, and rubidium may complement and enhance the molecular and cellular complexity of human during exercise, eradicate exercise-induced muscle damage, and strengthen antioxidant capability against oxidative stress. The details of these studies are described in Table 11.

3.10. Treatment for Stomach Ulcer. DSW can reduce ulcer area as well as apoptotic signalling in acetic acidinduced duodenal ulcers. It had upregulated antioxidant and enhanced $\mathrm{Bcl}-2$ and thioredoxin reductase 1 expression in a study that used rats [36]. In that study, DSW ingestion provides intestinal protection via the antioxidant and antiapoptotic mechanisms of selenium. The details of this study are described in Table 12.

3.11. Prevention of Cancer. DSW is potential to prevent cancer. Its application can inhibit human breast cancer cell lines' migratory ability in a wound-healing assay. The inhibitory effects of DSW on breast cancer invasion/metastasis that uses MDA-MB-231 cells appears to be mediated through TGF- $\beta$ and Wnt5a signalling, resulting in attenuated expression of CD44 [37]. In a study that uses the noninvasive MCF-7 cells, DSW treatment resulted in the inhibition of TPA-induced migration and MMP-9 activity with a concomitant decrease in mRNA levels of MMP-9, TGF- $\beta$, Wnt5a, and Wnt3a [37]. DSW also improves the quality of green tea prepared with it, in which it enhanced the production of epigallocatechin gallate (EGCG), which could potentially act as an inhibitor for $\mathrm{N}$-nitrosation, which can induce mutagenic and cell damaging reactions [38]. The details of the studies regarding effects of DSW on cancer are described in Table 13.

3.12. Improvement in Antibacterial Activity. DSW has promising effects on antibacterial activity. The findings of its antibacterial activities were proven in the studies using the in vitro, in vivo, and clinical model as described in Table 14 .

3.13. Treatment for Cataract. DSW application can delay cataract development $[40,41]$. This effect is associated with the presence of $\mathrm{Mg}$ and Ca content in DSW. The details of these studies are described in Table 15.

3.14. Recovery from Osteoporosis. DSW has therapeutic potential on osteoporosis. DSW at hardness 1000 showed significant increase in proliferation of osteoblastic cell (MC3T3). In the in vivo study that uses DSW for 4 months, bone mineral density (BMD) was strongly enhanced followed by the significantly increased trabecular numbers through microCT examination. Biochemistry analysis showed that serum alkaline phosphatase (ALP) activity was decreased. BMSCs treated with DSW showed increase of osteogenic differentiation markers such as BMP2, RUNX2, OPN, and OCN and enhanced colony forming abilities, compared to the control group. The results demonstrated the regenerative potentials of DSW on osteogenesis, showing that it could potentially be applied in osteoporosis therapy as a complementary and alternative medicine (CAM). The details of these studies are described in Table 16. 
TABLE 7: Effects of deep sea water on obesity.

\begin{tabular}{|c|c|c|c|}
\hline $\begin{array}{l}\text { Type of } \\
\text { study } \\
\text { model }\end{array}$ & $\begin{array}{l}\text { Experimental method } \\
\text { [subject (age/weight), } \\
\text { treatment dosage, duration of Major activity } \\
\text { treatment] }\end{array}$ & Mechanism of action & Reference \\
\hline
\end{tabular}

[subject (age/weight)

model treatment]

C2C12 cells, DSW 100, 500,

In vitro 1000, 1500, and $2000 \quad$ Increased mitochondrial 1,2 , and 3 days study hardness, indicated time of 0 , biogenesis and function.

Enhanced gene expression of peroxisome

proliferator-activated receptor gamma coactivator $1 \alpha$

(PGC-1a), nuclear respiratory factor-1 (NRF-1), and

mitochondrial transcription factor A (TFAM);

mitofusin-1/2 (MFN1/2) and dynamin-related protein 1

(DRP1) for mitochondrial fusion; optic atrophy 1 (OPA1)

for mitochondrial fission; translocase of outer

mitochondrial membrane 40 (TOMM40) and translocase

of inner mitochondrial membrane 44 (TIMM44) for

mitochondrial protein import; carnitine

palmitoyltransferase $1 \alpha(\mathrm{CPT} 1 \alpha)$ and medium-chain acyl-CoA dehydrogenase (MCAD) for fatty acid oxidation; and cytochrome $\mathrm{c}(\mathrm{CytC})$ for oxidative phosphorylation. Increased mitochondria staining, citrate synthase (CS) activity, CytC oxidase activity, NAD+ to NADH ratio, and the phosphorylation of signalling molecules such as AMPK and sirtuin 1 (SIRT1).

Reduced expression mRNA levels of PPAR $\gamma$ and $\mathrm{C} / \mathrm{EBP} \alpha$ and protein levels of fatty acid binding protein and adiponectin.

In vitro 3T3-L1 cells, DSW 100, 500, Decreased lipid study and 1000 hardness, 3 days accumulation.

HFD C57BL/6J mice (6

In vivo weeks), DSW 500, 1000, and Enhanced mitochondrial

study 2000 hardness, ad libitum, 20 biogenesis in muscles. weeks

Improved mitochondrial DNA (mtDNA) content in the muscles of HFD-induced obese mice.

Enhanced expression of PGC-1 $\alpha, \mathrm{NRF} 1$, and mtTFA.

Enhanced estrogen-related receptor $\alpha(\mathrm{ERR} \alpha), \operatorname{PPAR} \alpha$, and PPAR $\delta$.

Suppressed body weight

gain.

Suppressed mRNA expression of key adipogenic genes such as PPAR $\gamma, \mathrm{C} / \mathrm{EBP} \alpha$, and aP2.

Increased the expression of GLUT4, adiponectin, and leptin.

Inhibited increase in adipocyte size.

HFD C57BL/6J mice (6-26

In vivo weeks), DSW 500, 1000, and

study 2000 hardness, ad libitum, 20 weeks

Suppressed the expression of adipogenic, lipogenic, lipolytic, and proinflammatory cytokine genes.

Increased the expression of adipokines and b-oxidation genes in fat.

Male C57BL/6J ob/ob mice,

In vivo DSW 1000 hardness, ad study libitum, 84 days
Decreased body weight gain by $7 \%$.

Reduced plasma glucose levels by $35.4 \%$.
Decreased the expressions of IL-6 and TNF-a.

Decreased the expressions of sterol regulatory

element-binding protein 1c (SREBP1c) and fatty acid synthase (Fas), which are involved in lipogenesis; adipose triglyceride lipase (ATGL) and hormone-sensitive lipase (HSL), which are involved in lipolysis.

Increased the expression of MCAD and CPT1 $\alpha$, which are involved in b-oxidation.

Increased phosphorylation of IRS-1, LKB1, AMPK, and mTOR in fat.

Increased glucose disposal.

Increased plasma protein levels of adiponectin.

Decreased plasma protein levels of resistin, RBP4, and

fatty acid binding protein.

Increased GLUT4 and AMP-activated protein kinase

levels in skeletal muscle tissue.

Decreased PPAR $\gamma$ and adiponectin in adipose tissue.

\section{Effects of Deep Sea Water in the Liver and Kidney Status}

From the available studies, DSW hardness which ranges from 0 to 1500 had caused no damage to liver and kidneys. In a study, through in vivo and clinical subjects, ALT, AST, and BUN levels showed that there is no significant difference between treated subjects and the controls. The details of these respective studies are described in Table 17.

\section{Functional Deep Sea Water with Other Substances}

DSW is very beneficial to health. Its uses are applied to many DSW by-products. For example, it can enhance the antibacterial activity of yogurt [44]. The green tea leaves that were soaked in DSW had an increase in the antioxidant and catechin properties [38]. These findings increase the value of DSW as a health-promoting water. Combination of DSW 
TABLE 8: Effects of deep sea water on diabetes.

\begin{tabular}{lll}
\hline $\begin{array}{l}\text { Type of study } \\
\text { model }\end{array}$ & $\begin{array}{l}\text { Experimental method [subject } \\
\text { (age/weight), treatment dosage, } \\
\text { duration of treatment] }\end{array}$ & Major activity \\
\hline & $\begin{array}{l}\text { Differentiated C2C12 cells, DSW } \\
\text { In vitro study }\end{array}$ & $\begin{array}{l}100,500,1000,1500, \text { and 2000 } \\
\text { hardness, } 1 \mathrm{hr}\end{array}$ \\
\end{tabular}

Mechanism of action

Reference

Stimulated the phosphorylation of IRS-1, LKB1, AMPK, and MTOR and improved impaired phosphorylation of these molecules.

Increased AMPK phosphorylation in

In vitro study

Matured 3T3-L1 cells, DSW 500, 1000 , and 2000 hardness, $1 \mathrm{hr}$

Increased glucose uptake.

3T3-L1 pre- and mature adipocytes.

Stimulated phosphoinositol-3-kinase and

AMPK pathway-mediated glucose uptake.

Increased adiponectin and leptin levels and reduced the levels of the proinflammatory cytokines IL- 6 and TNF- $\alpha$.

Improved architecture of pancreatic islets of Langerhans and enhanced insulin secretion from $\beta$-cells.

Stimulated the phosphorylation of IRS-1, LKB1, AMPK, and mTOR and improved impaired phosphorylation of these molecules in muscle.

Streptozotocin- (STZ-) induced diabetic male ICR mice (4-9

In vivo study weeks), DSW 1000, 2000, and 4000 hardness, ad libitum, 4 weeks
Improved impaired glucose tolerance.

Regulated blood glucose levels by inhibited glucose production and enhanced glucose uptake via regulation of gene expression.
Downregulated the expression of phosphoenolpyruvate carboxykinase (PEPCK) and glucose 6-phosphatase (G6Pase), both of which are required for gluconeogenesis; glucokinase (GK) and citrate synthase (CS), both of which are required for glucose oxidation; and liver glycogen phosphorylase (LGP), which is required for glycogenolysis.

Upregulated glycogen synthase (GS) expression.

Upregulated the expression of GLUT1 and GLUT4 in skeletal muscle, which are required for glucose transport; glucokinase and citrate synthase, which are required for glucose oxidation; and acyl-CoA oxidase (ACO), CPT1 $\alpha$, and $\mathrm{MCAD}$, which are required for $\beta$-oxidation.

Recovered size of the pancreatic islets of Langerhans and increased the secretion

Improved impaired glucose of insulin and glucagon. tolerance. Increased adiponectin levels.

Suppressed the expression of hepatic genes involved in glucogenesis,

Decreased IL- 6 and TNF- $\alpha$ levels.

HFD-induced diabetic male

In vivo study C57BL/6J mice (6-25 weeks), DSW 500, 1000, and 2000 hardness, ad libitum, 20 weeks glycogenolysis, and glucose oxidation.

Increased glucose uptake, $\beta$-oxidation, and glucose oxidation in muscle. Improved impaired AMPK phosphorylation in the muscles and livers. 
TABLE 8: Continued.

\begin{tabular}{llll}
\hline $\begin{array}{l}\text { Type of study } \\
\text { model }\end{array}$ & $\begin{array}{l}\text { Experimental method [subject } \\
\text { (age/weight), treatment dosage, } \\
\text { duration of treatment] }\end{array}$ & Major activity & Mechanism of action \\
\hline & & & $\begin{array}{l}\text { Increased glucose disposal. } \\
\text { Increased adiponectin levels in plasma. }\end{array}$ \\
In vivo study & $\begin{array}{l}\text { Male C57BL/6J ob/ob mice, } \\
\text { DSW 1000 hardness, ad libitum, }\end{array}$ & $\begin{array}{l}\text { Reduced glucose levels in } \\
\text { plasma by 35.4\%. }\end{array}$ & $\begin{array}{l}\text { Decreased plasma protein levels of } \\
\text { resistin, RBP4, and fatty acid binding } \\
\text { protein. }\end{array}$ \\
& 84 days & & $\begin{array}{l}\text { Increased GLUT4 and AMP-activated } \\
\text { protein kinase levels in skeletal muscle } \\
\text { tissue. }\end{array}$ \\
\hline
\end{tabular}

TABLE 9: Effects of deep sea water on skin diseases.

\begin{tabular}{lll}
\hline $\begin{array}{l}\text { Type of study } \\
\text { model }\end{array}$ & $\begin{array}{l}\text { Experimental method [subject } \\
\text { (age/weight), treatment dosage, Major activity } \\
\text { duration of treatment] }\end{array}$ & Mechanism of action \\
\hline
\end{tabular}

\begin{tabular}{|c|c|c|c|}
\hline In vivo study & $\begin{array}{l}\text { Male NC/Nga mice ( } 6 \text { weeks), } \\
2 \% \text { concentrated DSW } \\
\text { (CDSW) ( } 7958.6 \text { hardness), } \\
10 \% \text { CDSW ( } 39793 \text { hardness), } \\
200 \mu \mathrm{L} \text { of test samples, five } \\
\text { times per week, six weeks }\end{array}$ & $\begin{array}{l}\text { Reduced severity of } \\
\text { symptoms in the skin } \\
\text { lesions, such as edema, } \\
\text { erythema, dryness, itching, } \\
\text { and transepidermal water } \\
\text { loss (TEWL). } \\
\text { Decreased epidermal } \\
\text { thickness and infiltration of } \\
\text { inflammatory cells. }\end{array}$ & $\begin{array}{l}\text { Inhibited upregulation of IgE, histamine, and } \\
\text { proinflammatory cytokines (TNF- } \alpha \text {, IL-1 } \beta \text {, and } \\
\text { IL-6) in the serum. } \\
\text { Downregulated CD } 4+/ C D 8+\text { ratio in spleen } \\
\text { lymphocyte by } 10 \% \text { CDSW. } \\
\text { Reduced the expression of IL- } 4 \text { and IL- } 10 \text { from } \\
\text { Th2 cells in the } 10 \% \text { CDSW-treated group. }\end{array}$ \\
\hline
\end{tabular}

Improved skin symptoms such as

33 patients (mean age 26 years, Improved skin symptoms. inflammation, lichenification, and cracking in range 1-50 years, 13 male and 20 Improved skin symptoms. female subjects), DSW 1000 hardness, $500 \mathrm{ml} /$ day, 6 months in the body. skin.

Restored essential minerals such as Se and reduced the level of toxic minerals such as mercury and lead.

\begin{tabular}{lll}
\hline Clinical study & $\begin{array}{l}50 \text { patients with allergic rhinitis } \\
\text { (age 22-50 years), DSW 1000 } \\
\text { hardness, 500 ml/day, 3 weeks }\end{array}$ & Improved skin symptoms.
\end{tabular}$\quad$\begin{tabular}{l}
$\begin{array}{l}\text { Reduced allergic skin responses and serum } \\
\text { levels of total IgE, Japanese cedar } \\
\text { pollen-specific IgE, IL-4, IL-6, IL-13, and IL-18. }\end{array}$ \\
\hline
\end{tabular}
pollen-specific IgE, IL-4, IL-6, IL-13, and IL-18.

with Sesamum indicum leaf extract (SIE) had prevented high fat diet-induced obesity, through AMPK activation in the visceral adipose tissue [45]. Furthermore, DSW has advantages for the development of functional fermentation food. The main factors of its increased health properties are due to it being able to increase functional metabolite production, intrinsic health functions of DSW, and the microbial use of mechanisms of converting the absorbed inorganic ions into highly bioavailable organic ions for the human body [48]. The detailed reviews regarding effects of DSW applications for the development of functional fermentation food are explained by Lee [48]. The detailed studies of functional deep sea water with other substances are described in Table 18.

\section{Discussion and Conclusion}

DSW originates from deep levels of the sea, which are far from contamination except for the natural occurrence of hazardous chemicals such as arsenic and mercury. It will usually undergo a process such as desalination to make it suitable for a particular purpose such as drinking water. The hardness of DSW of up to 1500 caused no cytotoxicity effects in the in vitro study [13]. However, the maximum hardness of it for human consumption should be remarked. The hardness values of water were estimated according to the following equation:

$$
\text { Hardness }=\operatorname{Mg}\left(\frac{\mathrm{mg}}{\mathrm{L}}\right) \times 4.1+\mathrm{Ca}\left(\frac{\mathrm{mg}}{\mathrm{L}}\right) \times 2.5 ;
$$

see [49].

The probability of physical, chemical, or bacteriological contaminants present in the drinking water has triggered compulsory actions by most authorities to ensure that the water is subjected to appropriate treatments prior to being supplied. This includes the step of adding chlorine into the drinking water as a treatment. However, chlorine causes an unpleasant taste and raises health concerns such as cancer due to its ability to accumulate within the body [50-52] Nowadays, it is becoming a trend to supply drinking water, through a vending machine that has the reverse osmosis 
TABle 10: Effects of Deep Sea Water on Hepatic Protection.

\begin{tabular}{|c|c|c|c|c|}
\hline $\begin{array}{l}\text { Type of study } \\
\text { model }\end{array}$ & $\begin{array}{l}\text { Experimental method [subject } \\
\text { (age/weight), treatment dosage, } \\
\text { duration of treatment] }\end{array}$ & Major activity & Mechanism of action & Reference \\
\hline In vitro study & $\begin{array}{l}\text { HepG2 cells, DSW 200, 400, 600, } \\
800 \text {, and } 1000 \text { hardness, } 24 \mathrm{hr}\end{array}$ & $\begin{array}{l}\text { Decreased lipids } \\
\text { accumulation. }\end{array}$ & $\begin{array}{l}\text { Inhibited the activity of HMGCR by } 30.2 \% \text {. } \\
\text { Increased the phosphorylation level of } \\
\text { AMPK by } 15.2 \% \text {. } \\
\text { Reduced p } 68 \text { of SREBP- } 1 \text { levels by } 55 \% \text {. } \\
\text { DSW of hardness } 600,800 \text {, and } 1,000 \\
\text { increased p } 68 \text { levels of SREBP- } 2 \text { by } 12,42 \text {, } \\
\text { and } 80 \% \text {, respectively. } \\
\text { DSW of hardness } 600,800 \text {, and } 1,000 \\
\text { increased level of CYP7A1 by } 41,115 \text {, and } \\
162 \% \text {, respectively. } \\
\text { DSW of hardness } 1,000 \text { increased Apo AI } \\
\text { content by } 20.3 \% \text {. }\end{array}$ & [19] \\
\hline
\end{tabular}

\begin{tabular}{lll}
\hline \multirow{2}{*}{ In vivo study } & $\begin{array}{l}\text { HFD male Wistar rats }(200-220 \mathrm{~g}), \\
\text { DSW 1,000 hardness, ad libitum, 4 } \\
\text { weeks }\end{array}$ & $\begin{array}{l}\text { DG in liver. } \\
\text { Improved liver function. }\end{array}$ \\
\hline
\end{tabular}

Decreased serum levels of AST and ALT.

\begin{tabular}{|c|c|c|c|c|}
\hline In vivo study & $\begin{array}{l}\text { HFD C57BL/6J mice ( } 6-26 \text { weeks), } \\
\text { DSW 500, 1000, and } 2000 \text { hardness, } \\
\text { ad libitum, } 20 \text { weeks }\end{array}$ & $\begin{array}{l}\text { Suppressed the expression } \\
\text { of genes involved in } \\
\text { lipogenesis and cholesterol } \\
\text { synthesis; and increased the } \\
\text { expression of genes related } \\
\text { to b-oxidation in liver. } \\
\text { Improved severe liver } \\
\text { steatosis. } \\
\text { Regulated mitochondrial } \\
\text { biogenesis and function in } \\
\text { liver. }\end{array}$ & $\begin{array}{l}\text { Decreased the expression of Fas and } \\
\text { acetyl-CoA carboxylase } 1 \text { (ACC1), which are } \\
\text { involved in lipogenesis, and liver X receptor } \\
\text { a (LXR a), and } \\
\text { 5-hydroxy-3-methylglutaryl-coenzyme A } \\
\text { reductase (HMG-CoAR), which are } \\
\text { involved in cholesterol metabolism. } \\
\text { Increased the expression of MCAD and } \\
\text { CPT1 } \alpha \text {, which are involved in b-oxidation. } \\
\text { Increased the phosphorylation of IRS-1, } \\
\text { LKB1, AMPK, and mTOR in liver. } \\
\text { Increased expression of PGCla, NRF1, Tfam, } \\
\text { and mtDNA content in liver. }\end{array}$ & [27] \\
\hline In vivo study & $\begin{array}{l}\text { HFD male Golden Syrian hamsters } \\
(5 \text { weeks), DSW 300, 900, and } 1500 \\
\text { hardness, ad libitum, } 6 \text { weeks }\end{array}$ & $\begin{array}{l}\text { Decreased lipids } \\
\text { accumulation in liver. } \\
\text { Regulated hepatic fatty acid } \\
\text { homeostasis. } \\
\text { Improved hepatic } \\
\text { antioxidative levels. } \\
\text { Attenuated hepatic damage. }\end{array}$ & $\begin{array}{l}\text { Increased daily faecal lipid and bile acid } \\
\text { outputs. } \\
\text { Upregulated genes of hepatic PPAR } \alpha \text {, } \\
\text { retinoid X receptor-alpha, and uncoupling } \\
\text { protein-2 (UCP-2) gene expression. } \\
\text { Maintained higher liver glutathione and } \\
\text { TEAC levels. } \\
\text { Reduced lipid peroxidation status (MDA } \\
\text { content) in liver. }\end{array}$ & [33] \\
\hline
\end{tabular}

system, from the treated wastewater and from the treated water pipeline. The process of water treatment will commonly cause reduction or loss of minerals. The increase in the availability of treated drinking water through processes such as reverse osmosis and chlorination should be put in high concern. Chlorine is not good for health. Furthermore, low nutrient in the drinking water can pose as a health threat to people that have nutrient deficiency. The desalinated DSW is usually added or concentrated with minerals, by the process of dilution, blending, or mixing it with concentrated minerals from the DSW $[2,4,19,53]$. These mineralized methods of desalinated seawater have been a popular method. Therefore, the desalinated DSW will normally regain its minerals that might have been lost through the desalination process again, compared to the packaged drinking water, which has lost most of its minerals through water treatments. Thus, DSDW is able to have numerous minerals constituents in the water compared to the common mineral water sources such as aquifer, which only contain minerals that originated readily from the source. It can be claimed that the mineral contents in the DSW are greater than in the groundwater sources.

Through the impressive findings of DSW benefits to health, it is suggested that its utilization should be promoted widely. The nutrients deficiency of population in a region could be provided with DSW. Adequate nutrient contents in the drinking water supply can contribute to a healthy population status in the area of supply. Areas which have lack of nutrient contents in the water supply are linked with the deficiency of nutrients among their populations. Nutritious water supply is crucial for the people. Prevalence of cardiovascular mortality and sudden death is $10 \%$ to $30 \%$ greater in the soft water areas, which has low $\mathrm{Mg}$ or $\mathrm{Ca}$ ions, compared to the hard water areas that have high $\mathrm{Mg}$ or $\mathrm{Ca}$ ions in the water supply [54]. Intake of hard water 
TABLE 11: Effects of deep sea water on fatigue.

\begin{tabular}{|c|c|c|c|c|}
\hline $\begin{array}{l}\text { Type of study } \\
\text { model }\end{array}$ & $\begin{array}{l}\text { Experimental method [subject } \\
\text { (age/weight), treatment dosage, } \\
\text { duration of treatment] }\end{array}$ & Major activity & Mechanism of action & Reference \\
\hline In vivo study & $\begin{array}{l}\text { Exercise-induced fatigue male Wistar } \\
\text { rats, DSW 100, and } 600 \text { hardness, } \\
\text { dosages }(6,12 \text {, and } 30 \mathrm{~mL} / \mathrm{kg} \cdot \mathrm{d})\end{array}$ & $\begin{array}{l}\text { Promoted the } \\
\text { endurance of rats } \\
\text { in exercise test. } \\
\text { Reduced } \\
\text { exhaustive period. }\end{array}$ & $\begin{array}{l}\text { Improved the ratio of lactic acid elimination to } \\
\text { lactic acid increment. } \\
\text { Reduced BUN level of rats fed with D100 in a } \\
\text { dosage of } 30 \mathrm{~mL} / \mathrm{kg} \cdot \mathrm{d} \text { and D } 600 \text { in dosages of } 6 \text {, } \\
12 \text {, and } 30 \mathrm{~mL} / \mathrm{kg} \cdot \mathrm{d} \text {. } \\
\text { Increased liver glycogen content in rats group } \\
\text { fed with D100 in a dosage of } 6 \mathrm{~mL} / \mathrm{kg} \cdot \mathrm{d} \text {. }\end{array}$ & {$[34]$} \\
\hline Clinical study & $\begin{array}{l}12 \text { healthy male volunteers (age } \\
24 \pm 0.8 \text { years; height } 171.8 \pm 1.5 \mathrm{~cm} \text {; } \\
\text { weight } 68.2 \pm 2.3 \mathrm{~kg} ; \mathrm{VO}_{2} \max \\
49.7 \pm 2.2 \mathrm{ml} \cdot \mathrm{kg}^{-1} \cdot \mathrm{min}^{-1} \text { ), } \\
\text { randomized, double-blind, } \\
\text { placebo-controlled, DSW } 710 \\
\text { hardness, fatiguing exercise conducted } \\
\text { for } 4 \mathrm{hr} \text { at } 30^{\circ} \mathrm{C}\end{array}$ & $\begin{array}{l}\text { Accelerated } \\
\text { recovery from } \\
\text { physical fatigue. }\end{array}$ & $\begin{array}{l}\text { Complete recovery of aerobic power within } 4 \mathrm{hr} \text {. } \\
\text { Elevated muscle power above placebo levels } \\
\text { within } 24 \mathrm{hr} \text {. } \\
\text { Increased circulating creatine kinase (CK) and } \\
\text { myoglobin; indicatives of exercise-induced } \\
\text { muscle damage, were completely eliminated, in } \\
\text { parallel with attenuated oxidative damage. }\end{array}$ & [35] \\
\hline
\end{tabular}

TABLE 12: Effects of deep sea water on stomach ulcer.

\begin{tabular}{|c|c|c|c|c|}
\hline $\begin{array}{l}\text { Type of study } \\
\text { model }\end{array}$ & $\begin{array}{l}\text { Experimental method } \\
\text { [subject (age/weight), } \\
\text { treatment dosage, } \\
\text { duration of treatment] }\end{array}$ & Major activity & Mechanism of action & Reference \\
\hline In vivo study & $\begin{array}{l}\text { Female Wistar rats } \\
(220-250 \mathrm{~g} \text { weight }) \text {, } \\
\text { DSW } 600(41 \mathrm{~mL} / \text { day }) \text {, } \\
\text { DSW } 1200 \text { ( } 39 \mathrm{~mL} / \text { day }) \text {, } \\
1 \text { week }\end{array}$ & $\begin{array}{l}\text { Reduced ulcer area as well as } \\
\text { apoptotic signalling in acetic } \\
\text { acid-induced duodenal ulcers. } \\
\text { DSW influenced oxidative stress } \\
\text { genes expression. } \\
\text { Upregulated antioxidant and } \\
\text { antiapoptotic genes and } \\
\text { downregulated proapoptotic } \\
\text { gene expression by DSW of } \\
\text { hardness } 600 \text { and 1200, } \\
\text { respectively. }\end{array}$ & $\begin{array}{l}\text { Increased pH value, scavenging } \mathrm{H}_{2} \mathrm{O}_{2} \text {, and } \\
\text { HOCl activity and reduced ORP value. } \\
\text { Enhanced Bcl-2 and thioredoxin reductase } 1 \\
\text { expression. } \\
\text { DSW1200 activated the expression of } \\
\text { flavin-containing monooxygenase } 2 \text { (Fmo2), } \\
\text { Gpx1, Gpx5, Gpx6, glutathione reductase (Gsr), } \\
\text { nitric oxide synthase 2, inducible (Nos2), } \\
\text { thioredoxin reductase } 1 \text { (Txnrd1), superoxide } \\
\text { dismutase } 1 \text { (Sod1), some antioxidant-related } \\
\text { genes, peroxiredoxin } 4 \text { (Prdx4), and } \\
\text { selenoprotein P plasma } 1 \text { (Sepp1). } \\
\text { DSW600 and DSW1200 upregulated Txnrd1 and } \\
\text { Bcl-2 and downregulated Bax, caspase 3, and } \\
\text { PARP in duodenal cells. } \\
\text { DSW } 600 \text { upregulated expression of } \\
\text { apoptosis-inducing factor, } \\
\text { mitochondrion-associated } 1 \text { (Aifm1), } \\
\text { DNA-damage-inducible, alpha (Gadd45a), } \\
\text { myeloid cell leukemia sequence } 1 \text { (Mcl 1), and } \\
\text { X-linked inhibitor of apoptosis (Xiap). } \\
\text { DSW } 600 \text { downregulated expression of } \\
\text { apoptosis inhibitor } 5 \text { BCL2-associated } \\
\text { athanogene (Api5), cell death-inducing } \\
\text { DFFA-like effector b (Ciedb), cytochrome c, and } \\
\text { somatic (Cycs), } \\
\text { Fas (TNF receptor superfamily, member 6), } \\
\text { growth arrest and mitogen activated protein } \\
\text { kinase } 1 \text { (Mapk1), PYD and CARD domain } \\
\text { containing (Pycard). } \\
\text { DSW } 1200 \text { upregulated expression of Fas, } \\
\text { Gadd45a, and Mcl1. } \\
\text { DSW } 1200 \text { downregulated expression of Aifm1, } \\
\text { Api5, Bag1, Cideb, Cycs, and Pycard. }\end{array}$ & {$[36]$} \\
\hline
\end{tabular}


TABLE 13: Effects of deep sea water on cancer.

\begin{tabular}{|c|c|c|c|}
\hline $\begin{array}{l}\text { Type of study } \\
\text { model }\end{array}$ & $\begin{array}{l}\text { Experimental method [subject (age/weight), } \\
\text { treatment dosage, duration of treatment] }\end{array}$ & Major activity & Reference \\
\hline In vitro study & $\begin{array}{l}\text { MDA-MB-231 cells, DSW 200, 400, 800, and } \\
1500 \text { hardness, } 2-3 \text { days }\end{array}$ & $\begin{array}{l}\text { Inhibited cells' migratory ability in a wound-healing } \\
\text { assay, mediated through TGF- } \beta \text { and Wnt5a } \\
\text { signalling, resulting in attenuated expression of } \\
\text { CD44. }\end{array}$ & [37] \\
\hline \multirow[t]{3}{*}{ In vitro study } & $\begin{array}{l}\text { Noninvasive MCF- } 7 \text { cells, DSW 200, } 400 \text {, } \\
800 \text {, and } 1500 \text { hardness, } 2-3 \text { days }\end{array}$ & $\begin{array}{l}\text { Inhibited TPA-induced migration and MMP-9 } \\
\text { activity with a concomitant decrease in mRNA levels } \\
\text { of MMP-9, TGF- } \beta \text {, Wnt5a, and Wnt3a. }\end{array}$ & [37] \\
\hline & $\begin{array}{l}\text { Green tea leaves were soaked in desalinated } \\
\text { DSW at } 75^{\circ} \mathrm{C} \text { for } 10 \mathrm{~min}\end{array}$ & $\begin{array}{l}\text { Increased nitrite scavenging activity from } \\
31.33 \pm 0.05 \text { to } 37.12 \pm 0.42 \% \text {. } \\
\text { Increased overall amounts of catechins. }\end{array}$ & {$[38]$} \\
\hline & $\begin{array}{l}\text { Salmonella Typhimurium TA98 and TA100, } \\
\text { Ames test, methanol extract of kochujang } \\
\text { added with sea tangle and deep sea water } \\
\text { salts (SDK), } 200 \mu \mathrm{g} / \text { plate }\end{array}$ & $\begin{array}{l}71.4 \% \text { inhibitory effect on the mutagenesis induced } \\
\text { by } 4 \text { NQO against TA } 98 \text { strain. } \\
56.1 \% \text { and } 83.6 \% \text { inhibitions on the mutagenesis } \\
\text { induced by } 4 \text { NQO and MNNG against TA100 strain. }\end{array}$ & [39] \\
\hline
\end{tabular}

TABLE 14: Effects of deep sea water on cataract.

\begin{tabular}{|c|c|c|c|c|}
\hline Type of study model & $\begin{array}{l}\text { Experimental method [subject (age/weight), } \\
\text { treatment dosage, duration of treatment] }\end{array}$ & Major activity & Mechanism of action & Reference \\
\hline In vivo study & $\begin{array}{l}\text { Male Shumiya cataract rat (5-15 weeks), } \\
\text { DSW }\left(\mathrm{Mg}^{2+}, 200 \mathrm{mg} / \mathrm{L}, \mathrm{Ca}^{2+} ; 71 \mathrm{mg} / \mathrm{L}\right), 9-10 \\
\text { weeks }\end{array}$ & $\begin{array}{l}\text { Delayed cataract } \\
\text { development. }\end{array}$ & $\begin{array}{l}\text { Reduced less opaque and } \\
\text { nitric oxide (NO) levels. }\end{array}$ & {$[40]$} \\
\hline In vivo study & $\begin{array}{l}\text { Male Shumiya cataract rat (5-15 weeks), } \\
\text { DSW containing Mg of 50, 200, and } \\
1000 \mathrm{mg} / \mathrm{L} \text {, respectively, } 9-10 \text { weeks }\end{array}$ & Delayed cataract onset. & $\begin{array}{l}\text { Mg suppressed Ca influx } \\
\text { into the lens. }\end{array}$ & [41] \\
\hline
\end{tabular}

TABLE 15: Effects of deep sea water on antibacterial activity.

\begin{tabular}{|c|c|c|c|}
\hline Type of study model & $\begin{array}{l}\text { Experimental method [subject (age/weight), } \\
\text { treatment dosage, duration of treatment] }\end{array}$ & Major activity & Reference \\
\hline In vitro study & $\begin{array}{l}\text { Five types ratio of DSW containing } \\
\text { magnesium : calcium }(\mathrm{Mg}: \mathrm{Ca}) \text { ratios of } 1: 2(\mathrm{~A}) \text {, } \\
1: 1(\mathrm{~B}), 3: 1(\mathrm{C}), 1: 0(\mathrm{D}) \text {, and } 0: 1(\mathrm{E}) \text { at different } \\
\text { concentrations to give levels of hardness of } 100 \text {, } \\
250,500 \text {, and } 1000 \text {; produced } 20 \text { types of samples } \\
\text { Sixteen } H \text {. pylori strains, clinical isolates were } \\
\text { obtained from patients with gastric cancer, gastric } \\
\text { ulcer, and normal gastric mucosa }\end{array}$ & $\begin{array}{l}\text { Inhibited bacterial growth and } \\
\text { mobility. }\end{array}$ & {$[42]$} \\
\hline In vitro study & $\begin{array}{l}\text { Sheep blood, } H \text {. pylori obtained from gastric } \\
\text { biopsy specimens of peptic ulcer patients, } 3 \text { to } 5 \\
\text { days }\end{array}$ & $\begin{array}{l}\text { DSW hardness of } 1200 \text { and } 2400 \\
\text { inhibited growth of } H \text {. pylori strains } \\
\text { by } 20 \% \text { and } 60 \% \text {, respectively. }\end{array}$ & {$[36]$} \\
\hline In vivo study & $\begin{array}{l}\text { Male Mongolian gerbils ( } 4 \text { weeks), DSW at } 5 \\
\text { different } \mathrm{Mg} / \mathrm{Ca} \text { ratios (hardness of 1000) were } \\
\text { administered for } 2 \text { weeks }\end{array}$ & $\begin{array}{l}\text { Decreased amount of } H \text {. pylori } \\
\text { colonized in stomach by treatment } \\
\text { with } 2 \text { types of DSW ratio which are } \\
\text { C and D. } \\
\text { Anti- } H \text {. pylori effects were observed } \\
\text { in } \geq 90 \% \text { of subjects. }\end{array}$ & {$[42]$} \\
\hline Clinical study & $\begin{array}{l}\text { Healthy subjects infected with } H \text {. pylori, DSW at } 5 \\
\text { different } \mathrm{Mg} / \mathrm{Ca} \text { ratios (hardness: 1000), } 1 \mathrm{~L} / \text { daily, } \\
10 \text { days }\end{array}$ & Reduced $\Delta 13 \mathrm{C}$ values. & {$[42]$} \\
\hline
\end{tabular}


TABLE 16: Effects of deep sea water on osteoporosis.

\begin{tabular}{|c|c|c|c|}
\hline Type of study model & $\begin{array}{l}\text { Experimental method [subject (age/weight), } \\
\text { treatment dosage, duration of treatment] }\end{array}$ & Major activity & Reference \\
\hline In vitro study & $\begin{array}{l}\text { Osteoblastic cell (MC3T3), DSW 50, 1000, and } \\
2000 \text { hardness, } 3 \text { days }\end{array}$ & Increased cells proliferation. & {$[43]$} \\
\hline In vitro study & $\begin{array}{l}\text { Bone marrow stromal cells (BMSCs), DSW } 1000 \\
\text { hardness, } 3 \text { days }\end{array}$ & Enhanced colony forming abilities. & {$[43]$} \\
\hline In vivo study & $\begin{array}{l}\text { Ovariectomized (OVX) SAMP8 mice ( } 4 \text { months), } \\
\text { DSW } 1000 \text { hardness, } 5.2 \mathrm{~mL} / \text { day, } 4 \text { months }\end{array}$ & $\begin{array}{l}\text { Enhanced bone mineral density. } \\
\text { Increased trabecular numbers through } \\
\text { micro-CT examination. } \\
\text { Decreased serum alkaline phosphatase } \\
\text { (ALP). } \\
\text { Increased osteogenic differentiation markers } \\
\text { such as BMP2, RUNX2, OPN, and OCN. }\end{array}$ & {$[43]$} \\
\hline
\end{tabular}

TABLE 17: Effects of deep sea water in the liver and kidney status.

\begin{tabular}{|c|c|c|c|}
\hline Type of study model & $\begin{array}{l}\text { Experimental method [subject (age/weight), } \\
\text { treatment dosage, duration of treatment] }\end{array}$ & Major activity & Reference \\
\hline In vivo study & $\begin{array}{l}\text { HFD male Wistar rats ( } 200-220 \mathrm{~g}), \text { DSW 1,000 } \\
\text { hardness, ad libitum, } 4 \text { weeks }\end{array}$ & $\begin{array}{l}\text { Improved liver function by the decrease } \\
\text { of serum levels of AST and ALT. }\end{array}$ & {$[19]$} \\
\hline In vivo study & $\begin{array}{l}\text { HFD male Golden Syrian hamsters ( } 5 \text { weeks), } \\
\text { DSW 300, 900, and } 1500 \text { hardness, ad libitum, } 6 \\
\text { weeks }\end{array}$ & $\begin{array}{l}\text { Attenuated serum AST values in hamsters } \\
\text { drinking DSW 300, 900, and } 1500 . \\
\text { Lower serum ALT values in hamsters } \\
\text { drinking DSW } 900 \text { and DSW } 1500 .\end{array}$ & [33] \\
\hline In vivo study & $\begin{array}{l}\text { CFD male New Zealand white rabbits } \\
(1500-2000 \mathrm{~g}) \text { fed diet containing } 3.75,37.5 \text {, and } \\
75 \mathrm{mg} / \mathrm{kg} \text { of } \mathrm{Mg} \text {, DSW } 1410 \text { hardness, } 8 \text { weeks }\end{array}$ & $\begin{array}{l}\text { No differences were observed in values of } \\
\text { AST and ALT. }\end{array}$ & {$[6]$} \\
\hline In vivo study & $\begin{array}{l}\text { Male hyperlipidemia rabbits (1.8-2.0 g), DSW } \\
1200 \text { hardness, } 150 \mathrm{ml} / \mathrm{d} \text {, ad libitum, } 12 \text { weeks }\end{array}$ & $\begin{array}{l}\text { No differences were observed in values of } \\
\text { AST and ALT. }\end{array}$ & {$[21]$} \\
\hline Clinical study & $\begin{array}{l}\text { Hypercholesterolemic individuals ( } 23 \text { men and } 19 \\
\text { women), DSW ( } 1410 \text { hardness), supplemented } \\
1050 \mathrm{~mL} \text { daily, } 6 \text { weeks }\end{array}$ & $\begin{array}{l}\text { No significant difference of ALT, AST, } \\
\text { and BUN levels between treated subjects } \\
\text { and controls. }\end{array}$ & {$[4]$} \\
\hline
\end{tabular}

has potential to decrease the risks of cardiovascular disease [55]. The importance of mineral contents in the drinking water is proven, when its intake is able to reduce calcium oxalate stone in the kidney of people that consume drinking water rich in minerals such as $\mathrm{Mg}$, $\mathrm{Ca}$, and bicarbonate [5658]. In contrast, consumption of low calcium content in the drinking water has resulted in the hip fracture incident in the Norwegian population [59]. Instead of epidemiological studies, researchers have identified the importance of mineral water content in the experimental studies. According to the study, the rabbits and men which consumed water with low mineral contents have higher risks of cardiovascular disease, compared to the group that consumed water with high mineral content [60]. The miracle of water to cure diseases has progressively been discussed. One of the mechanisms of mineral water to treat diseases is through the existence of minerals which are capable of activating the aquaporin genes, which are responsible for transporting water within the cells [61]. Lack of aquaporin gene activation has been linked to many disease occurrences [62]. Minerals in the DSW are plenty and thus could be a major factor in curing diseases.

Some areas may have lack of nutrients in the soil and crops, which may pose as health threats to its consumers. The soil provides minerals to the plants, and through the plants the minerals go to the animals and humans [63]. Referring to the chain, it is a health threat to people that usually rely on the crops and animals as their main nutrients provider. For instance, nutrient deficiency in the land of South Africa was associated with many diseases occurrences such as thyroid, iodine deficiency disorders (IDD), Mseleni Joint Disease (MJD), HIV-AIDS, and Mg insufficiency [64]. Besides that, the groundwater could be contaminated with man-made activities including the industries, agriculture, and logging. These could pose as a threat to the residents that use groundwater as a source for drinking water. For instance, agricultural activities have caused an increase in the 
TABLE 18: Effects of functional deep sea water with other substances.

\begin{tabular}{|c|c|c|c|c|}
\hline $\begin{array}{l}\text { Type of study } \\
\text { model }\end{array}$ & $\begin{array}{l}\text { Experimental method [subject } \\
\text { (age/weight), treatment dosage, } \\
\text { duration of treatment] }\end{array}$ & Major activity & Mechanism of action & Reference \\
\hline In vivo study & $\begin{array}{l}\text { Outbred albino female ICR mice } \\
(20-26 \mathrm{~g}) \text {, yogurt containing DSW, } \\
10.3 \mathrm{~g} \text { hardness of } \mathrm{CaCO}_{3} / \mathrm{L}, 8 \text { weeks }\end{array}$ & $\begin{array}{l}\text { Increased populations of intestinal } \\
\text { lactic acid bacteria. } \\
\text { Decreased the activity of serum AST } \\
\text { and ALT. } \\
\text { Reduced TC, TC to HDL-C ratio, } \\
\text { TAG, and HDL-C in serum. }\end{array}$ & ND. & {$[44]$} \\
\hline In vivo study & $\begin{array}{l}\text { HFD-induced obesity ICR ( } 4 \\
\text { weeks), DSW, and DSW + } \\
125 \mathrm{mg} / \mathrm{kg} \text { SIE (DSS), ad libitum, } \\
\text { treated with SIE once per day for } 8 \\
\text { weeks }\end{array}$ & $\begin{array}{l}\text { Reduced body weights in the DSW } \\
\text { group by } 3.95 \% \text { and in the DSS group } \\
\text { by } 8.42 \% \text {, respectively. } \\
\text { Decreased plasma glucose levels in the } \\
\text { DSW group by } 14.9 \% \text { and in the DSS } \\
\text { group by } 36.4 \% \text {, respectively. } \\
\text { Decreased serum levels of glucose, } \\
\text { TAG, and leptin. } \\
\text { Decreased insulin resistance index } \\
\text { (HOMA-IR) values for the } \\
\text { DSS-treated group by } 38.2 \% \text {. }\end{array}$ & $\begin{array}{l}\text { Decreased size of the epididymal } \\
\text { white, retroperitoneal white, and } \\
\text { scapular brown adipose tissue. } \\
\text { Increased levels of } \\
\text { phosphorylated AMPK and its } \\
\text { substrate and ACC in mice } \\
\text { epididymal adipose tissues. } \\
\text { Upregulated the expression levels } \\
\text { of lipolysis-associated mRNA, } \\
\text { PPAR- } \alpha \text {, cluster of differentiation } \\
36 \text { (CD36), and energy } \\
\text { expenditure-associated mRNA } \\
\text { and UCP2 and CPT1 epididymal } \\
\text { adipose tissues. } \\
\text { Suppressed the expression of } \\
\text { SREBP1 at the mRNA level. }\end{array}$ & {$[45]$} \\
\hline In vivo study & $\begin{array}{l}\text { Green tea leaves were soaked in } \\
\text { desalinated DSW at } 75^{\circ} \mathrm{C} \text { for } 10 \mathrm{~min}\end{array}$ & Increased antioxidant activity. & $\begin{array}{l}\text { Increased } 2 \text {, } \\
\text { 2-diphenyl-1-picrylhydrazyl } \\
\text { (DPPH) radical scavenging } \\
\text { activities by } 83.98 \% \text { and } \\
\text { increased reducing power by } \\
15 \% \text {. } \\
\text { Increased nitrite scavenging } \\
\text { activity from } 31.33 \pm 0.05 \text { to } \\
37.12 \pm 0.42 \% \text {. } \\
\text { Increased amounts of catechins } \\
\text { and caffeine. }\end{array}$ & {$[38]$} \\
\hline
\end{tabular}

ND: not described.

nitrate concentration of groundwater in the area of Machang, Malaysia, resulting from the fertilizer application [65]. DSW which is far from man-made contamination could provide a safe water source. DSW is rarely polluted, has no or slight bacteria existence, and is very pure $[2,8,66]$.

Furthermore, nutrients deficiency among the people was also associated with the types of daily food intake. For instance, the regular consumption of phytate content foods had caused the zinc deficiency among Korean people [67]. Phytate impairs the zinc bioavailability. Thus, choosing the right foods is crucial for nutrient intake. Dynamic activities in today's life had caused the tendency for people to choose fast, instant, and easy prepared foods. These kinds of foods usually contain a small amount of nutrients, which is not the most promising source of nutrients intake. Minerals in food may also be lost during cooking [68-70]. In a nutshell, nutrients intake should not solely rely on food intake. DSW has lots of minerals to supply, and could be provided in the form of health drinks or water supply, as an alternative to maintain nutrients source. The roles of minerals in the water to heal disease and maintain health has already been recognized. Water can be classified into a few categories based on its total salt content, its mineral biological activity, and its ion mineral composition [71]. The effort to put DSW as a water source that is beneficial for health should be enhanced. The studies regarding types of mineral water have also been progressively carried out. Examples of these studies can be referred to Astel et al. [72], included in the discussion about the types of minerals available in the water, types of available water treatments, associated regulations, and therapeutic potentials of mineral water. The study to classify DSW into particular types of water based on the types of production should be established, as there is a great therapeutic potential about it yet to be discovered.

Ideally, countries with the accessibility to pump up water from DSW should consider maximizing the use of it. Perhaps, the only limitations are the technology provider and cost of production, rather than reachable sources to the DSW itself. Technologies that are involved may include desalination, low vacuum temperature, and ocean thermal energy conversion 
(OTEC). OTEC is a kind of technology which could produce water as a by-product from its process, without the extensive cost [73]. There are many great findings from the studies regarding DSW applications in the in vitro models such as using 3T3L-1 cells, and in the in vivo models such as using mice, and rabbits. However, the potential health benefits of its applications in the clinical studies are not widely established. Hence, the study of its applications especially to the human health should be conducted more. DSW is worthy of further investigations and could be developed as medicated water in the prevention and treatment of many health problems, especially lifestyle-related diseases.

\section{Competing Interests}

The authors declare that there are no competing interests.

\section{Acknowledgments}

The authors would like to acknowledge the UTM Ocean Thermal Energy Centre (Universiti Teknologi Malaysia), the Malaysian-Japan International Institute of Technology (Universiti Teknologi Malaysia), and the Institute Marine Biotechnology (Universiti Malaysia Terengganu) for the support of this study.

\section{References}

[1] H. S. Hwang, H. A. Kim, S. H. Lee, and J. W. Yun, "Antiobesity and antidiabetic effects of deep sea water on ob/ob mice," Marine Biotechnology, vol. 11, no. 4, pp. 531-539, 2009.

[2] S.-I. Katsuda, T. Yasukawa, K. Nakagawa et al., "Deep-sea water improves cardiovascular hemodynamics in kurosawa and kusanagi-hypercholesterolemic (KHC) rabbits," Biological and Pharmaceutical Bulletin, vol. 31, no. 1, pp. 38-44, 2008.

[3] A. Z. Aris, R. C. Y. Kam, A. P. Lim, and S. M. Praveena, "Concentration of ions in selected bottled water samples sold in Malaysia," Applied Water Science, vol. 3, no. 1, pp. 67-75, 2013.

[4] Z.-Y. Fu, F. L. Yang, H.-W. Hsu, and Y.-F. Lu, "Drinking deep seawater decreases serum total and low-density lipoproteincholesterol in hypercholesterolemic subjects," Journal of Medicinal Food, vol. 15, no. 6, pp. 535-541, 2012.

[5] C.-L. Hsu, Y.-Y. Chang, C.-H. Chiu et al., "Cardiovascular protection of deep-seawater drinking water in high-fat/cholesterol fed hamsters," Food Chemistry, vol. 127, no. 3, pp. 1146-1152, 2011.

[6] M.-J. Sheu, P.-Y. Chou, W.-H. Lin et al., "Deep sea water modulates blood pressure and exhibits hypolipidemic effects via the AMPK-ACC pathway: An in Vivo Study," Marine Drugs, vol. 11, no. 6, pp. 2183-2202, 2013.

[7] S. Ueshima, H. Fukao, K. Okada, and O. Matsuo, "Suppression of the release of type-1 plasminogen activator inhibitor from human vascular endothelial cells by Hawaii deep sea water," Pathophysiology, vol. 9, no. 2, pp. 103-109, 2003.

[8] M. M. Takahashi and P. Huang, "Novel renewable natural resource of Deep Ocean Water ( DOW ) and their current and future practical applications," Kuroshio Science, vol. 6, no. 1, pp. 101-113, 2012.

[9] M. Michelle and K. A. Beerman, "The major minerals and water," in Nutritional Sciences: From Fundamentals to Food, pp. 517-525, Peter Marshall, 7th edition, 2007.
[10] Y. Ouchi, R. E. Tabata, K. Stergiopoulos, F. Sato, A. Hattori, and H. Orimo, "Effect of dietary magnesium on development of atherosclerosis in cholesterol-fed rabbits," Arteriosclerosis, Thrombosis, and Vascular Biology, vol. 10, no. 5, pp. 732-737, 1990.

[11] Q. Faryadi, "The magnificent effect of magnesium to human health: a critical review," International Journal of Applied Science and Technology, vol. 2, no. 3, pp. 118-126, 2012.

[12] R. R. Watson, T. Kokot, M. Muc-Wierzgoń, E. NowakowskaZajdel, and S. Dzięgielewska-Gęsiak, Nutrition in the Prevention and Treatment of Abdominal Obesity, Elsevier, 2014.

[13] H. S. Hwang, S. H. Kim, Y. G. Yoo et al., "Inhibitory effect of deep-sea water on differentiation of 3T3-L1 adipocytes," Marine Biotechnology, vol. 11, no. 2, pp. 161-168, 2009.

[14] M. B. Zemel, "Regulation of adiposity and obesity risk by dietary calcium: mechanisms and implications," Journal of the American College of Nutrition, vol. 21, no. 2, pp. 146S-151S, 2002.

[15] S. Lewicki, R. Zdanowski, M. Krzyzowska et al., "The role of chromium III in the organism and its possible use in diabetes and obesity treatment," Annals of Agricultural and Environmental Medicine, vol. 21, no. 2, pp. 331-335, 2014.

[16] A. Pechova and L. Pavlata, "Chromium as an essential nutrient: a review," Veterinarni Medicina, vol. 52, no. 1, pp. 1-18, 2007.

[17] Z. Krejpcio, "Essentiality of chromium for human nutrition and health," Polish Journal of Environmental Studies, vol. 10, no. 6, pp. 399-404, 2001.

[18] A. P. Seale, L. A. De Jesus, M.-C. Park, and Y.-S. Kim, "Vanadium and insulin increase adiponectin production in 3T3-L1 adipocytes," Pharmacological Research, vol. 54, no. 1, pp. 30-38, 2006.

[19] S. He, J. Hao, W. Peng, P. Qiu, C. Li, and H. Guan, "Modulation of lipid metabolism by deep-sea water in cultured human liver (HepG2) cells," Marine Biotechnology, vol. 16, no. 2, pp. 219-229, 2014.

[20] M.-H. Chang, B.-S. Tzang, T.-Y. Yang, Y.-C. Hsiao, H.-C. Yang, and Y.-C. Chen, "Effects of deep-seawater on blood lipids and pressure in high-cholesterol dietary mice," Journal of Food Biochemistry, vol. 35, no. 1, pp. 241-259, 2011.

[21] M. Miyamura, S. Yoshioka, A. Hamada et al., "Difference between deep seawater and surface seawater in the preventive effect of atherosclerosis," Biological and Pharmaceutical Bulletin, vol. 27, no. 11, pp. 1784-1787, 2004.

[22] M. Kimura, H. Tai, K. Nakagawa, Y. Yokoyama, Y. Ikegami, and T. Takeda, "Effect of drinking water without salt made from deep sea water in lipid metabolism of rats," in Proceedings of the MTS/IEEE Techno-Ocean '04: Bridges Across the Oceans (Ocean '04), pp. 320-321, Kobe, Japan, November 2004.

[23] M. Kimura, R. Takeda, T. Takeda et al., "Effect cholesterol level in plasma of rats by drinking high magnesium water made from deep sea water," in Proceedings of the MTS/IEEE Oceans (OCEANS '15), pp. 1965-1966, Honolulu, Hawaii, USA, November 2001.

[24] S. Yoshioka, A. Hamada, T. Cui et al., "Pharmacological activity of deep-sea water: examination of hyperlipemia prevention and medical treatment effect," Biological and Pharmaceutical Bulletin, vol. 26, no. 11, pp. 1552-1559, 2003.

[25] J.-L. Shen, T.-C. Hsu, Y.-C. Chen et al., "Effects of deep-sea water on cardiac abnormality in high-cholesterol dietary mice," Journal of Food Biochemistry, vol. 36, no. 1, pp. 1-11, 2012.

[26] B. G. Ha, J.-E. Park, H.-J. Cho, and Y. H. Shon, "Stimulatory effects of balanced deep sea water on mitochondrial biogenesis 
and function," PLoS ONE, vol. 10, no. 6, Article ID e0129972, 2015.

[27] B. G. Ha, J.-E. Park, E. J. Shin, and Y. H. Shon, "Effects of balanced deep-sea water on adipocyte hypertrophy and liver steatosis in high-fat, diet-induced obese mice," Obesity, vol. 22, no. 7, pp. 1669-1678, 2014.

[28] B. G. Ha, J.-E. Park, E. J. Shin, and Y. H. Shon, "Modulation of glucose metabolism by balanced deep-sea water ameliorates hyperglycemia and pancreatic function in streptozotocininduced diabetic mice," PLoS ONE, vol. 9, no. 7, Article ID e102095, 2014.

[29] B. G. Ha, E. J. Shin, J.-E. Park, and Y. H. Shon, "Anti-diabetic effect of balanced deep-sea water and its mode of action in highfat diet induced diabetic mice," Marine Drugs, vol. 11, no. 11, pp. 4193-4212, 2013.

[30] J.-P. Bak, Y.-M. Kim, J. Son, C.-J. Kim, and E.-H. Kim, “Application of concentrated deep sea water inhibits the development of atopic dermatitis-like skin lesions in NC/Nga mice," BMC Complementary and Alternative Medicine, vol. 12, article no. 108, 2012.

[31] Y. Hataguchi, H. Tai, H. Nakajima, and H. Kimata, "Drinking deep-sea water restores mineral imbalance in atopic eczemal dermatitis syndrome," European Journal of Clinical Nutrition, vol. 59, no. 9, pp. 1093-1096, 2005.

[32] H. Kimata, H. Tai, and H. Nakajima, "Reduction of allergic skin responses and serum allergen-specific $\operatorname{IgE}$ and $\operatorname{IgE}$-inducing cytokines by drinking deep-sea water in patients with allergic rhinitis," Oto-Rhino-Laryngologia Nova, vol. 11, no. 6, pp. 302303, 2001.

[33] I.-S. Chen, Y.-Y. Chang, C.-L. Hsu et al., "Alleviative effects of deep-seawater drinking water on hepatic lipid accumulation and oxidation induced by a high-fat diet," Journal of the Chinese Medical Association, vol. 76, no. 2, pp. 95-101, 2013.

[34] S.-T. Wang, D.-F. Hwang, R.-H. Chen et al., "Effect of deep sea water on the exercise-induced fatigue of rats," Journal of Food and Drug Analysis, vol. 17, no. 2, pp. 133-141, 2009.

[35] C.-W. Hou, Y.-S. Tsai, W.-H. Jean et al., "Deep ocean mineral water accelerates recovery from physical fatigue," Journal of the International Society of Sports Nutrition, vol. 10, article 7, 2013.

[36] C.-C. Yang, C.-A. Yao, Y.-R. Lin, J.-C. Yang, and C.-T. Chien, "Deep-sea water containing selenium provides intestinal protection against duodenal ulcers through the upregulation of Bcl2 and thioredoxin reductase 1," PLOS ONE, vol. 9, no. 7, Article ID e96006, 2014.

[37] S. Kim, S.-Y. Chun, D.-H. Lee, K.-S. Lee, and K.-S. Nam, "Mineral-enriched deep-sea water inhibits the metastatic potential of human breast cancer cell lines," International Journal of Oncology, vol. 43, no. 5, pp. 1691-1700, 2013.

[38] M.-S. Bae and S.-C. Lee, "Effect of deep sea water on the antioxidant activity and catechin content of green tea," Journal of Medicinal Plants Research, vol. 4, no. 16, pp. 1662-1667, 2010.

[39] S.-S. Ham, H.-J. Choi, S.-H. Kim, H.-T. Oh, and M.-J. Chung, "Antimutagenic and cytotoxic effects of Kochujang extracts added deep sea water salt and sea tangle," Journal of the Korean Society of Food Science and Nutrition, vol. 37, no. 4, pp. 410-415, 2008.

[40] N. Nagai and Y. Ito, "Delay of cataract development in the Shumiya cataract rat by water containing enhanced concentrations of magnesium and calcium," Current Eye Research, vol. 32, no. 5, pp. 439-445, 2007.

[41] N. Nagai, Y. Ito, M. Inomata et al., "Delay of cataract development in the Shumiya cataract rat by the administration of drinking water containing high concentration of magnesium ion," Biological and Pharmaceutical Bulletin, vol. 29, no. 6, pp. 1234-1238, 2006.

[42] M. Kawada and H. Takeuchi, "Antibacterial activities of refined deep seawater on Helicobacter pylori," Journal of Genetic Syndromes \& Gene Therapy, vol. s1, pp. 2-8, 2013.

[43] H.-Y. Liu, M.-C. Liu, M.-F. Wang et al., "Potential osteoporosis recovery by deep sea water through bone regeneration in SAMP8 mice," Evidence-based Complementary and Alternative Medicine, vol. 2013, Article ID 161976, 2013.

[44] S. M. Kang, J. W. Jhoo, J. I. Pak, I. K. Kwon, S. K. Lee, and G. Y. Kim, "Effect of yogurt containing deep sea water on healthrelated serum parameters and intestinal microbiota in mice," Journal of Dairy Science, vol. 98, no. 9, pp. 5967-5973, 2015.

[45] H. Yuan, S. Chung, Q. Ma, L. Ye, and G. Piao, "Combination of deep sea water and Sesamum indicum leaf extract prevents high-fat diet-induced obesity through AMPK activation in visceral adipose tissue," Experimental and Therapeutic Medicine, vol. 11, no. 1, pp. 338-344, 2016.

[46] K. Itoh, T. Kawasaki, and M. Nakamura, “The effects of high oral magnesium supplementation on blood pressure, serum lipids and related variables in apparently healthy Japanese subjects," British Journal of Nutrition, vol. 78, no. 5, pp. 737-750, 1997.

[47] J. W. Yun, "Possible anti-obesity therapeutics from nature-a review," Phytochemistry, vol. 71, no. 14-15, pp. 1625-1641, 2010.

[48] C.-L. Lee, "The advantages of deep ocean water for the development of functional fermentation food," Applied Microbiology and Biotechnology, vol. 99, no. 6, pp. 2523-2531, 2015.

[49] Standard Methods for the Examination of Water and Wastewater. \#2340 Hardness, American Public Health Association/American Water Works Association/Water Environment Federation, Washington, DC, USA, 20th edition, 1998.

[50] C. M. Villanueva, F. Fernández, N. Malats, J. O. Grimalt, and M. Kogevinas, "Meta-analysis of studies on individual consumption of chlorinated drinking water and bladder cancer," Journal of Epidemiology and Community Health, vol. 57, no. 3, pp. 166173, 2003.

[51] S. E. Hrudey, L. C. Backer, A. R. Humpage et al., "Evaluating evidence for association of human bladder cancer with drinkingwater chlorination disinfection by-products," Journal of Toxicology and Environmental Health\&Part B: Critical Reviews, vol. 18, no. 5, pp. 213-241, 2015.

[52] C. M. Villanueva, M. Kogevinas, S. Cordier et al., "Assessing exposure and health consequences of chemicals in drinking water: current state of knowledge and research needs," Environmental Health Perspectives, vol. 122, no. 3, pp. 213-221, 2014.

[53] M. Rygaard, E. Arvin, and P. J. Binning, "The valuation of water quality: effects of mixing different drinking water qualities," Water Research, vol. 43, no. 5, pp. 1207-1218, 2009.

[54] P. Garzon and M. J. Eisenberg, "Variation in the mineral content of commercially available bottled waters: implications for health and disease," American Journal of Medicine, vol. 105, no. 2, pp. 125-130, 1998.

[55] K. Anne, "Magnesium and calcium in drinking water and heart diseases," Encyclopedia of Environmental Health, pp. 535-544, 2011.

[56] M. Mirzazadeh, M. G. Nouran, K. A. Richards, and M. Zare, "Effects of drinking water quality on urinary parameters in men with and without urinary tract stones," Urology, vol. 79, no. 3, pp. 501-507, 2012. 
[57] R. Siener, A. Jahnen, and A. Hesse, "Influence of a mineral water rich in calcium, magnesium and bicarbonate on urine composition and the risk of calcium oxalate crystallization," European Journal of Clinical Nutrition, vol. 58, no. 2, pp. 270276, 2004.

[58] A. L. Rodgers, "The influence of South African mineral water on reduction of risk of calcium oxalate kidney stone formation," South African Medical Journal, vol. 88, no. 4, pp. 448-451, 1998.

[59] C. Dahl, A. J. Søgaard, G. S. Tell et al., "Population data on calcium in drinking water and hip fracture: an association may depend on other minerals in water. A NOREPOS Study," Bone, vol. 81, pp. 292-299, 2015.

[60] J. Luo, Q. Zhao, L. Zhang et al., "The consumption of lowmineral bottled water increases the risk of cardiovascular disease: an experimental study of rabbits and young men," International Journal of Cardiology, vol. 168, no. 4, pp. 44544456, 2013.

[61] Y. Kitagawa, C. Liu, and X. Ding, "The influence of natural mineral water on aquaporin water permeability and human natural killer cell activity," Biochemical and Biophysical Research Communications, vol. 409, no. 1, pp. 40-45, 2011.

[62] P. Agre and D. Kozono, "Aquaporin water channels: molecular mechanisms for human diseases," FEBS Letters, vol. 555, no. 1, pp. 72-78, 2003.

[63] U. C. Gupta and S. C. Gupta, "Sources and deficiency diseases of mineral nutrients in human health and nutrition: a review," Pedosphere, vol. 24, no. 1, pp. 13-38, 2014.

[64] Y. Hu, E. A. Ehli, J. Kittelsrud et al., "Lipid-lowering effect of berberine in human subjects and rats," Phytomedicine, vol. 19, no. 10, pp. 861-867, 2012.

[65] N. Islami, S. H. Taib, I. Yusoff, and A. A. Ghani, "Integrated geoelectrical resistivity, hydrochemical and soil property analysis methods to study shallow groundwater in the agriculture area, Machang, Malaysia," Environmental Earth Sciences, vol. 65, no. 3, pp. 699-712, 2012.

[66] Y. Tsuchiya, A. Watanabe, N. Fujisawa et al., "Effects of desalted deep seawater on hematologic and blood chemical values in mice," The Tohoku Journal of Experimental Medicine, vol. 203, no. 3, pp. 175-182, 2004.

[67] H. Joung, G. Nam, S. Yoon, J. Lee, J. E. Shim, and H. Y. Paik, "Bioavailable zinc intake of Korean adults in relation to the phytate content of Korean foods," Journal of Food Composition and Analysis, vol. 17, no. 6, pp. 713-724, 2004.

[68] M. Krzysik, H. Grajeta, and A. Prescha, "Chromium content in selected convenience and fast foods in Poland," Food Chemistry, vol. 107, no. 1, pp. 208-212, 2008.

[69] N. Gerber, M. R. L. Scheeder, and C. Wenk, "The influence of cooking and fat trimming on the actual nutrient intake from meat," Meat Science, vol. 81, no. 1, pp. 148-154, 2009.

[70] H. Hosseini, M. Mahmoudzadeh, M. Rezaei et al., "Effect of different cooking methods on minerals, vitamins and nutritional quality indices of kutum roach (Rutilus frisii kutum)," Food Chemistry, vol. 148, pp. 86-91, 2014.

[71] L. Petraccia, G. Liberati, S. Giuseppe Masciullo, M. Grassi, and A. Fraioli, "Water, mineral waters and health," Clinical Nutrition, vol. 25, no. 3, pp. 377-385, 2006.

[72] A. Astel, "Mineral water: types of mineral water," in Encyclopedia of Food and Health, pp. 763-766, Elsevier, Amsterdam, Netherlands, 2016.

[73] M. Gauthier, L. Golmen, and D. Lennard, "Ocean Thermal Energy Conversion (OTEC) and Deep Ocean Water Applications (DOWA): market opportunities for european industry," in
New and Renewable Technologies for Sustainable Development, N. H. Afgan and M. D. G. Carvalho, Eds., pp. 655-666, Springer, Boston, Mass, USA, 2002. 


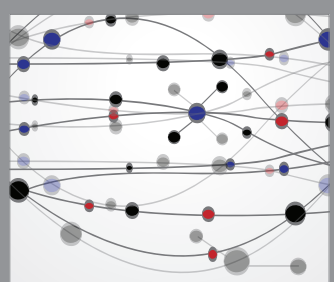

The Scientific World Journal
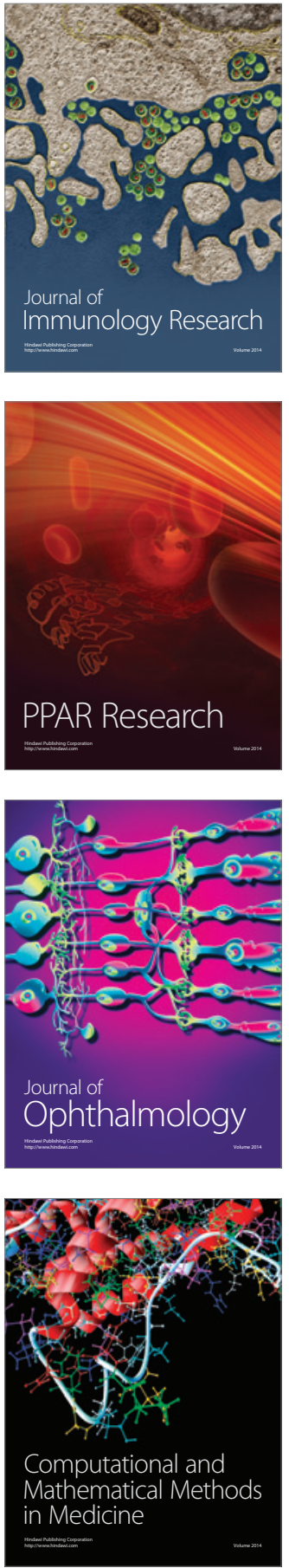

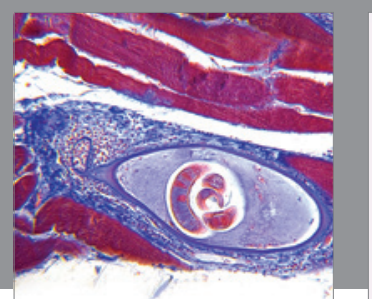

Gastroenterology Research and Practice

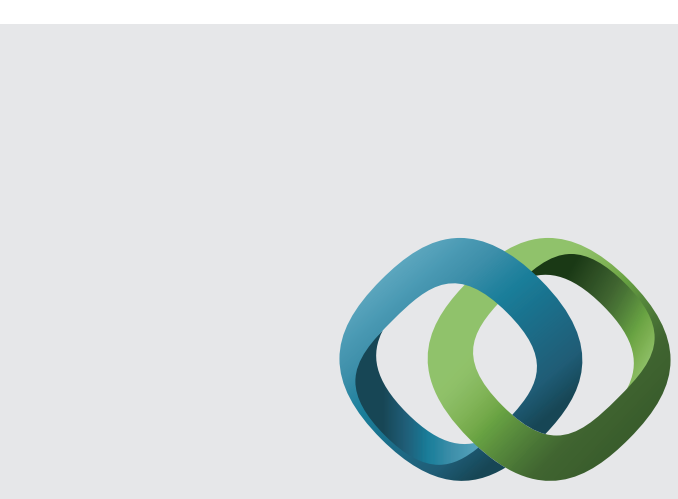

\section{Hindawi}

Submit your manuscripts at

http://www.hindawi.com
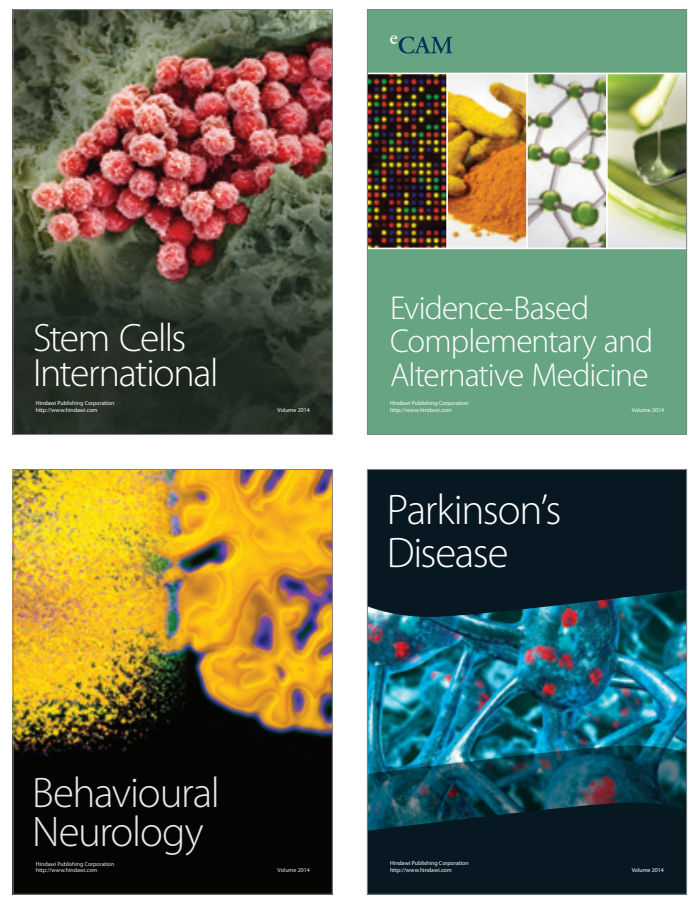
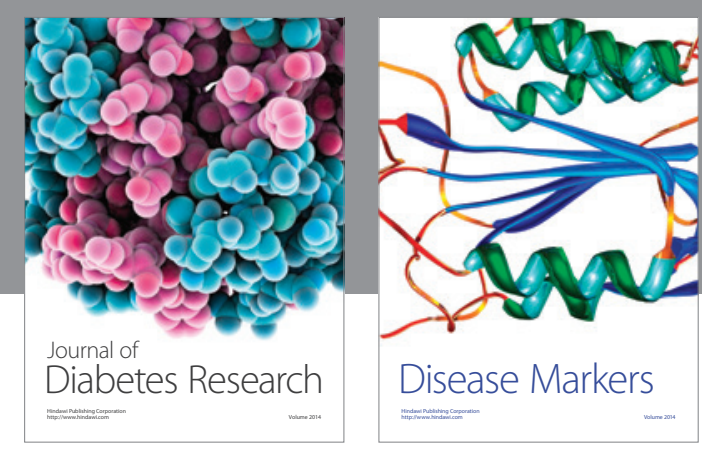

Disease Markers
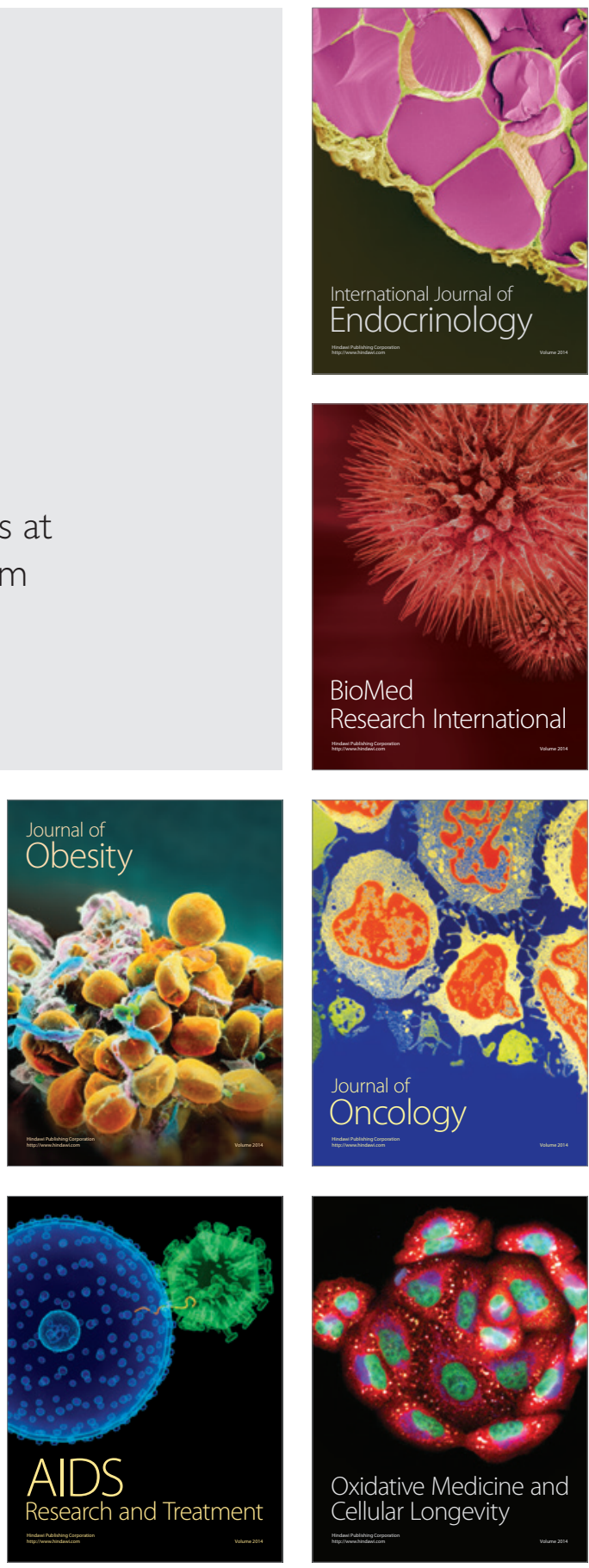